\title{
Nitrate Origin in the Zagreb Aquifer System
}

\author{
Zoran Kovač $\left(\mathbb{D},{ }^{1}\right.$ Zoran Nakić, ${ }^{1}$ Jadranka Barešić, $^{2}$ and Jelena Parlov ${ }^{1}$ \\ ${ }^{1}$ Department of Geology and Geological Engineering, Faculty of Mining, Geology and Petroleum Engineering, Zagreb 10000, Croatia \\ ${ }^{2}$ Division of Experimental Physics, Ruđer Bošković Institute, Zagreb 10000, Croatia
}

Correspondence should be addressed to Zoran Kovač; zoran.kovac@rgn.hr

Received 28 May 2018; Accepted 26 August 2018; Published 5 November 2018

Academic Editor: Lionel Esteban

Copyright (C) 2018 Zoran Kovač et al. This is an open access article distributed under the Creative Commons Attribution License, which permits unrestricted use, distribution, and reproduction in any medium, provided the original work is properly cited.

\begin{abstract}
Nitrates are among the most common groundwater contaminants worldwide, and the same situation is present within the Zagreb aquifer. The Zagreb aquifer presents the only source of potable water for inhabitants of the City of Zagreb and part of Zagreb County. Isotopic composition of water $\left(\delta^{2} \mathrm{H}\right.$ and $\left.\delta^{18} \mathrm{O}\right)$ and nitrates $\left(\delta^{15} \mathrm{~N}\right.$ and $\left.\delta^{18} \mathrm{O}\right)$, groundwater chemistry, and molar ratios, in combination with correlation and multivariate statistical methods, have been used for the estimation of nitrate origin. Nitrate stable isotopes excluded synthetic fertilizer as the main source of nitrate contamination. They showed insignificant influence of denitrification on nitrate concentrations but could not define the main source of nitrate contamination. The usage of molar ratios, especially $\mathrm{NO}_{3}{ }^{-} / \mathrm{K}^{+}$, helped to clarify this issue. Waste water has been defined as the main source of nitrate contamination. All results indicate that nitrogen in a large extent enters the aquifer in the form of ammonium ion, which is transformed to nitrates by the process of nitrification.
\end{abstract}

\section{Introduction}

Groundwater nitrate contamination presents one of the main environmental problems in the world [1-5]. The most important issue related to the effective management of nitrate contamination is the definition of its origin and the understanding of fate and transport of nitrates through the aquifer. Nitrate is negatively charged and very soluble. It has high mobility and potential for loss from the unsaturated zone, generally through leaching $[6,7]$. Nitrate leaching through the unsaturated zone is the consequence of a complex interaction between many different factors, which vary in time [1]. When nitrates reach groundwater, their movement mainly depends on transport processes, mostly advection and dispersion. Additionally, geochemical processes, such as denitrification, as well as aerobic and anaerobic conditions, play a very important role in the stability of different nitrogen compounds. Nitrates are dominantly found in an aerobic environment where they have high mobility. Identification of a nitrate source can be very difficult. Nitrates can occur naturally but also can be the consequence of anthropogenic sources. Major anthropogenic sources are synthetic fertilizers, manure, and different types of waste water, i.e., municipal waste water and septic tanks in the rural areas. Although different indicators of aerobic and anaerobic conditions exist in aquifers, dissolved oxygen concentrations are the most important one. The boundary between aerobic and anaerobic conditions is close to $1 \mathrm{mg} / \mathrm{l}$ of dissolved oxygen [8].

Within the Zagreb aquifer system, good positive, statistically significant correlation between nitrates and dissolved oxygen concentrations has been observed [9]. Furthermore, it has been shown that aerobic conditions prevail in the Zagreb aquifer, except in the eastern part of the City of Zagreb and Zagreb County, where the aquifer deepens [10]. Anthropogenically caused, elevated nitrate concentrations have been determined in the groundwater of the Zagreb aquifer [10-12], which presents the only source of potable water for the citizens of the City of Zagreb and part of Zagreb County. Nitrates have been recognized as one of the five major contaminants in the Zagreb aquifer system [11], and two main areas with elevated nitrate concentrations were identified $[10,12]$. In addition, descending nitrate concentration trends have been established in almost all parts of the Zagreb aquifer system [13]. Although the presence of nitrate contamination in the Zagreb aquifer is 


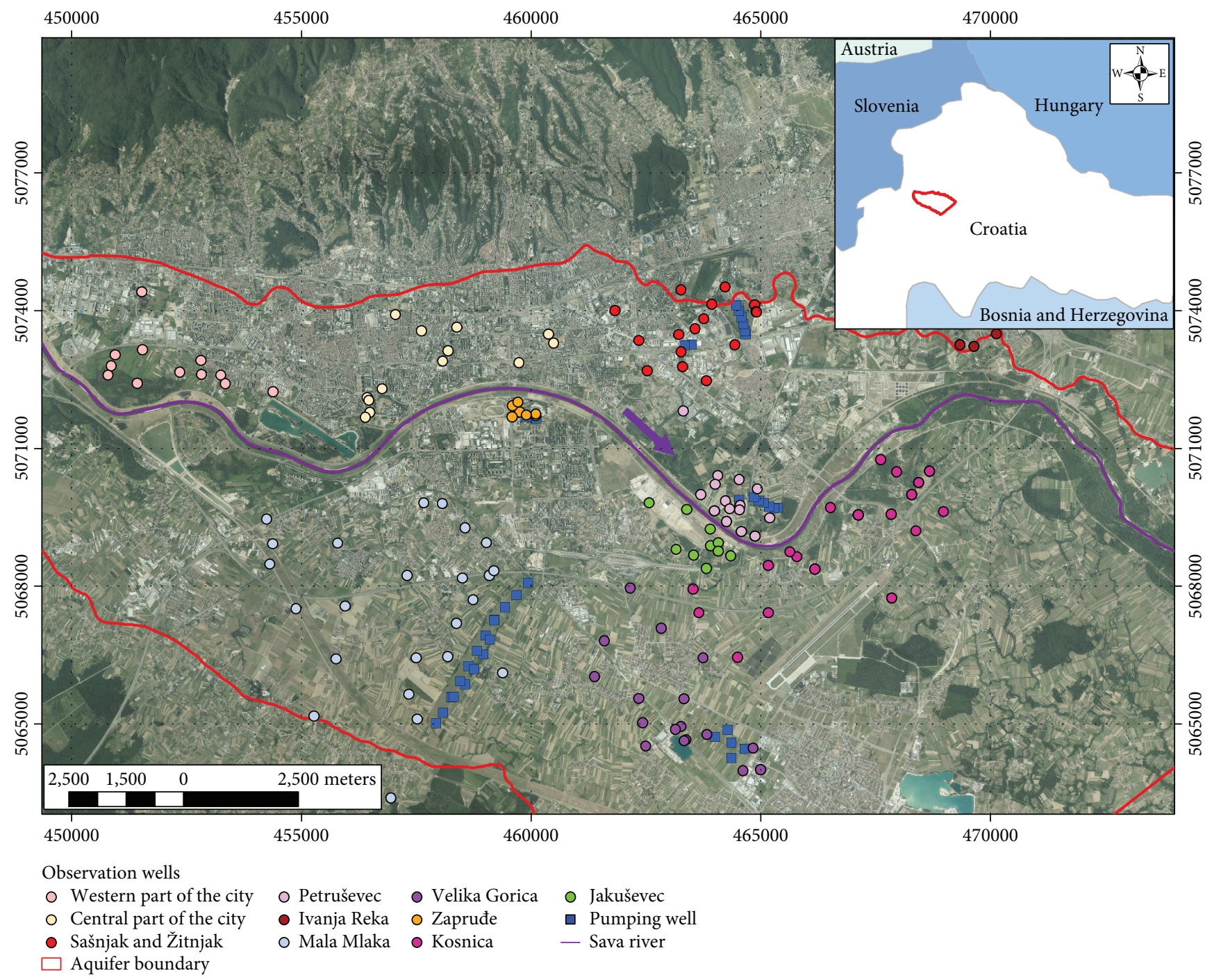

FIGURE 1: Research area and spatially grouped observation wells.

undoubtedly confirmed, previous research did not deal with the estimation of nitrate origin.

Determination and evaluation of nitrate stable isotope composition, i.e., $\delta^{15} \mathrm{~N}$ and $\delta^{18} \mathrm{O}$ from nitrates, present one of the main tools for the identification of nitrates sources, as well as for defining the significance of denitrification on nitrate concentrations. The frequent use of nitrate stable isotopes started at the beginning of the $21^{\text {st }}$ century by development of analytical techniques which enabled accurate, precise, fast, and inexpensive analysis: "ion-exchange" method [14, 15], "bacterial denitrification method" [16-18], and "cadmium reduction method" [19]. Although the use of $\delta^{15} \mathrm{~N}_{-} \mathrm{NO}_{3}{ }^{-}$in the identification of nitrate sources dates back to the 1970s [20], development of these methods has enabled an extensive, successful application in a large number of studies [4, 21-27]. However, the application of nitrate stable isotopes has limitations, mostly due to overlap of the isotope composition of nitrates from waste water and manure. It has been shown that both waste water and manure are enriched in
${ }^{15} \mathrm{~N}$ relative to other types of nitrogen sources, mostly ranging from $+7 \%$ o to $+15 \%$ [ [3]. Even though evaluation of $\delta^{18} \mathrm{O}-\mathrm{NO}_{3}{ }^{-}$can distinguish nitrate from precipitation, synthetic fertilizer, or nitrification process, it cannot help in discerning nitrates from manure and waste water. To overcome this issue, $\delta^{11} \mathrm{~B}$ is very often used in the combination with $\delta^{15} \mathrm{~N}_{-} \mathrm{NO}_{3}{ }^{-}[25,28-30]$. Unfortunately, due to the absence of $\mathrm{B}$ concentration data in groundwater of the Zagreb aquifer, this isotopic technique could not be used in this research.

Groundwater geochemistry and different statistic tools, especially multivariate statistical analysis, in combination with nitrate stable isotope composition, can be very useful in the estimation of the nitrate origin. Different research $[31,32]$ showed very good correlation between $\mathrm{NO}_{3}{ }^{-}, \mathrm{Na}^{+}$, and $\mathrm{Cl}^{-}$, related to urban contamination sources, for example, to leaking sewage system or municipal waste, while other research $[33,34]$ linked the existence of these correlations to animal waste. When statistical correlation of these parameters is not significant, it can be assumed that the 


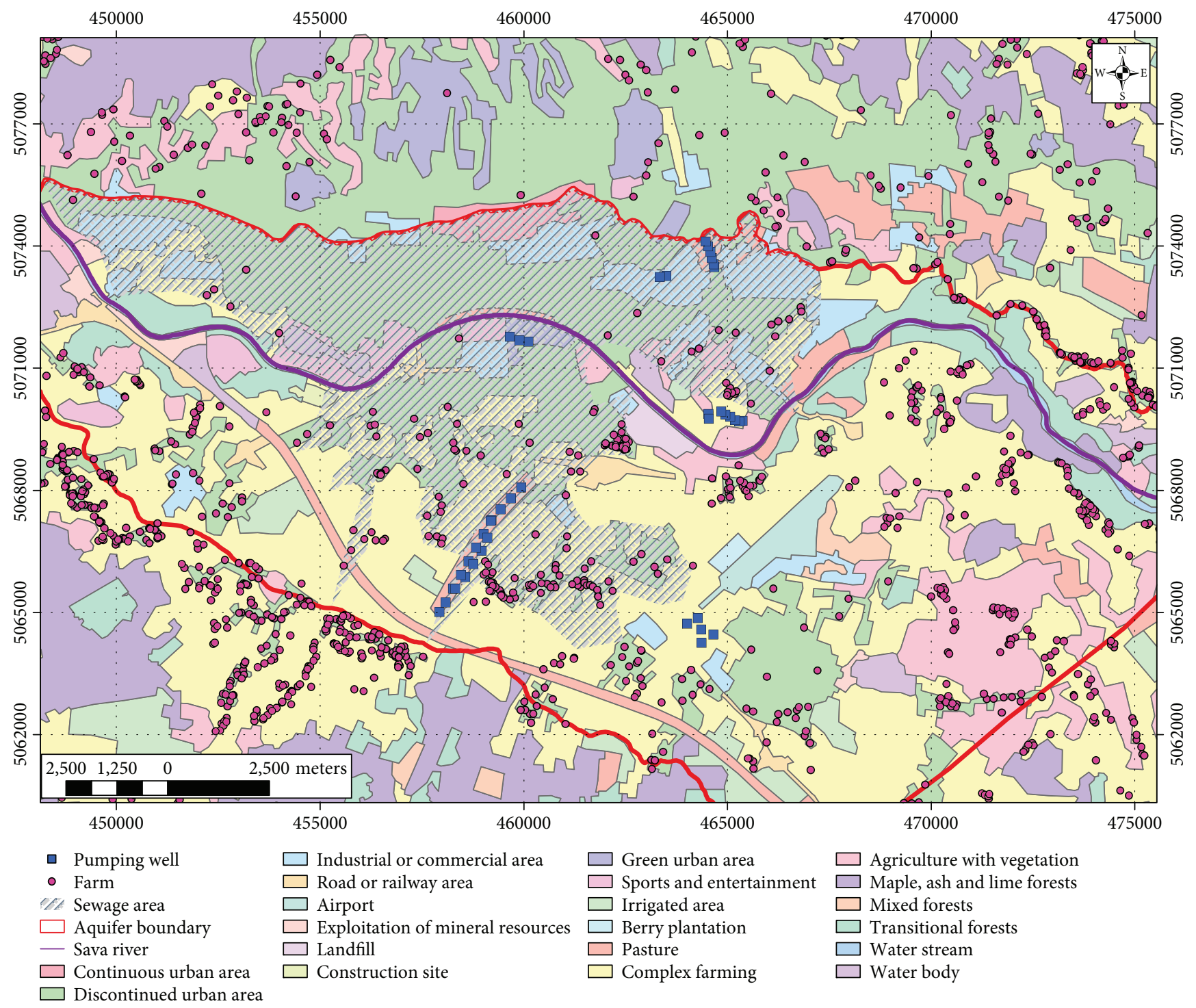

FIgURE 2: Potential contaminants in the area of the Zagreb aquifer system.

presence of nitrogen is related to different sources [32]. According to some authors, very good correlations between $\mathrm{NO}_{3}{ }^{-}, \mathrm{Ca}^{2+}$, and $\mathrm{Mg}^{2+}$ indicate that nitrate concentrations originate from a unique source, generally synthetic fertilizers and/or manure [21]. Also, it was shown that exploration of molar ratios between $\mathrm{NO}_{3}{ }^{-}, \mathrm{Cl}^{-}$, and $\mathrm{K}^{+}$could be useful in the determination of nitrate origin [23]. Higher $\mathrm{Cl}^{-}$concentrations are more characteristic for urban sources, while a higher $\mathrm{NO}_{3}^{-} / \mathrm{K}^{+}$molar ratio is more likely associated with the manure application, and a lower molar ratio is possibly related to urban sewage effluent. The molar ratio of $\mathrm{NO}_{3}{ }^{-}$to $\mathrm{K}^{+}$characteristic for synthetic fertilizer should be much lower with regard to manure but higher with regard to waste water $[35,36]$. Correlation and multivariate statistical analysis, especially factor and cluster analysis, are also very often used in the research of groundwater chemistry [31, 33, 37-39].

The main goal of the research presented in this paper was to estimate nitrate origin and to evaluate the significance of the denitrification process in the groundwater of the Zagreb aquifer system. For this purpose, multi-isotope data and groundwater geochemistry data including ion molar ratios, as well as correlation and multivariate statistical analyses, were used.

\section{Site Description}

The Zagreb aquifer system is located in the northwest part of the Republic of Croatia, covering approximately $350 \mathrm{~km}^{2}$ (see Figure 1).

It is designated as a part of the country's strategic water reserves, which emphasizes the necessity of its protection from different anthropogenic influences. The wide region is characterized by great variability in land use, pedology, topology, lithology, and hydraulic properties of the aquifer.

The Zagreb aquifer system consists of Quaternary sediments deposited during the Middle and Upper Pleistocene and Holocene. Pleistocene deposits belong to lacustrine- 


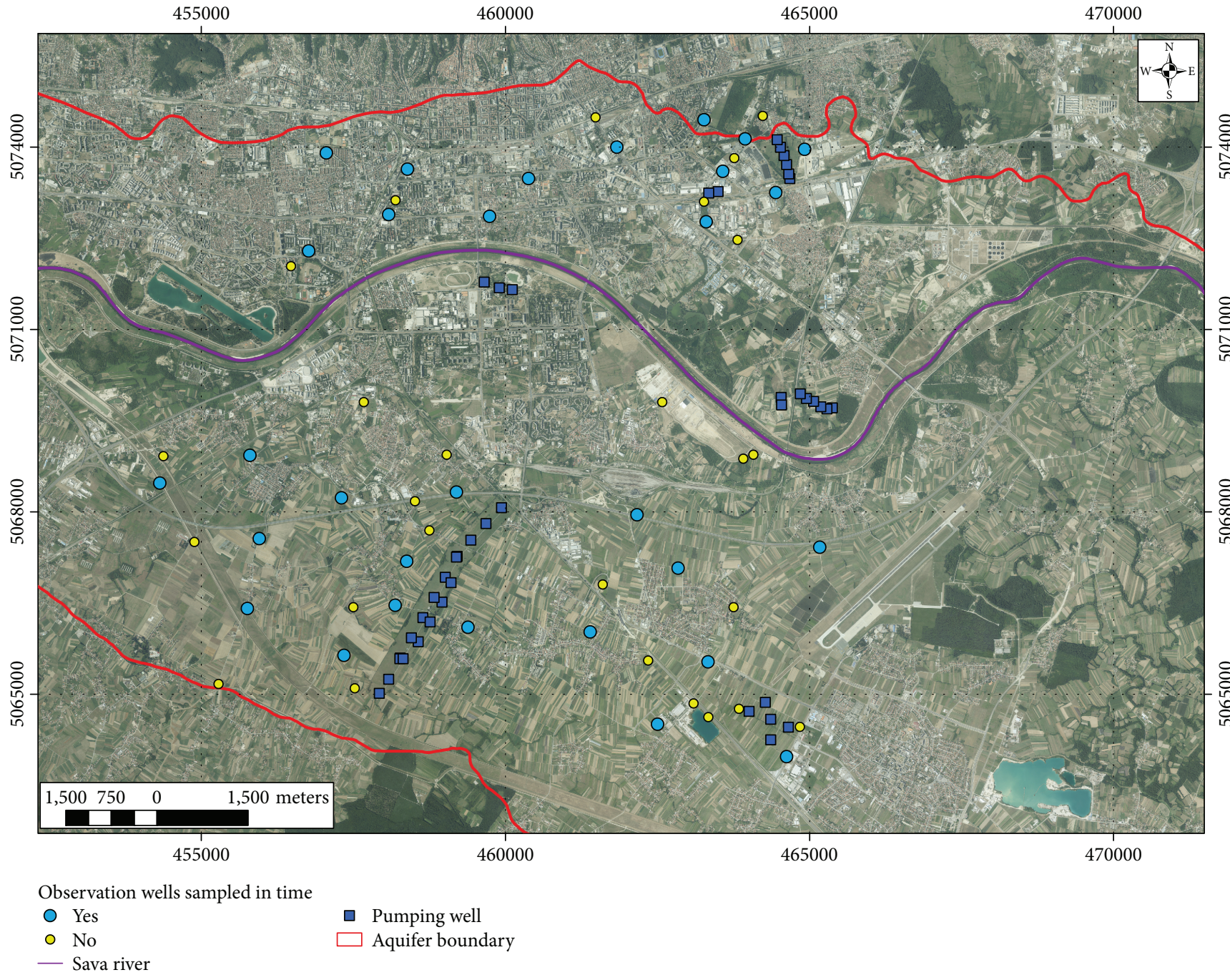

Figure 3: Location of sampled observation wells in the area of the Zagreb aquifer system ("Yes": sampled in the first and second phases; "No": sampled only in the first phase).

marshy deposits, while Holocene deposits are alluvial [40, 41]. The Middle and Upper Pleistocene sediments consist of gravel, sand, and clay. Clasts in coarse grained sediments are mostly of siliciclastic composition due to the local source of sediments from nearby mountains. Holocene sediments are somewhat more coarse grained than Pleistocene sediments and have a significant amount of carbonate clast. This was the result of the change in the source of the material which was transported by the Sava River from the Alps [42]. Hydrogeologically, the Zagreb aquifer system consists of an overburden, shallow, and deep aquifer layer. The thickness of the unsaturated zone, generally disturbed by the anthropogenic influence, varies from 2 to $8 \mathrm{~m}$ and is highly permeable in some parts, especially under humid conditions $[43,44]$. This allows transport of contaminants to the groundwater. The thickness of the shallow Holocene aquifer is from 5 to $40 \mathrm{~m}$, while deeper Pleistocene aquifer thickness can be up to $60 \mathrm{~m}$, which means that maximum aquifer depth can reach up to $100 \mathrm{~m}$ [45]. Holocene and Pleistocene aquifer layers are hydraulically connected. The Holocene part of the aquifer system is in direct contact with the Sava River. Stream-aquifer interaction is more pronounced in the vicinity of the Sava River [46]. Regional groundwater flow is from W-NW to E-SE, which coincides with the Sava River flow, while local groundwater flow changes frequently, strongly depending on the Sava River fluctuations, i.e., duration and intensity of hydrological conditions. Geochemical stratification of the Zagreb aquifer system is recognized along the depth and in time and space, which mostly depends on the proximity of the Sava River [47].

Due to industrial and agricultural development, and growth of the City of Zagreb and Zagreb County, anthropogenic influence on groundwater quality has significantly increased in the last decades. Nitrates are recognized as one of the main groundwater contaminants [11], while descending nitrate concentration trends have been observed in almost all parts of the Zagreb aquifer system, studied at different observational scales [13]. Two main parts of the Holocene aquifer are contaminated with nitrates. One area is located on the left bank of the Sava River, in the urban 


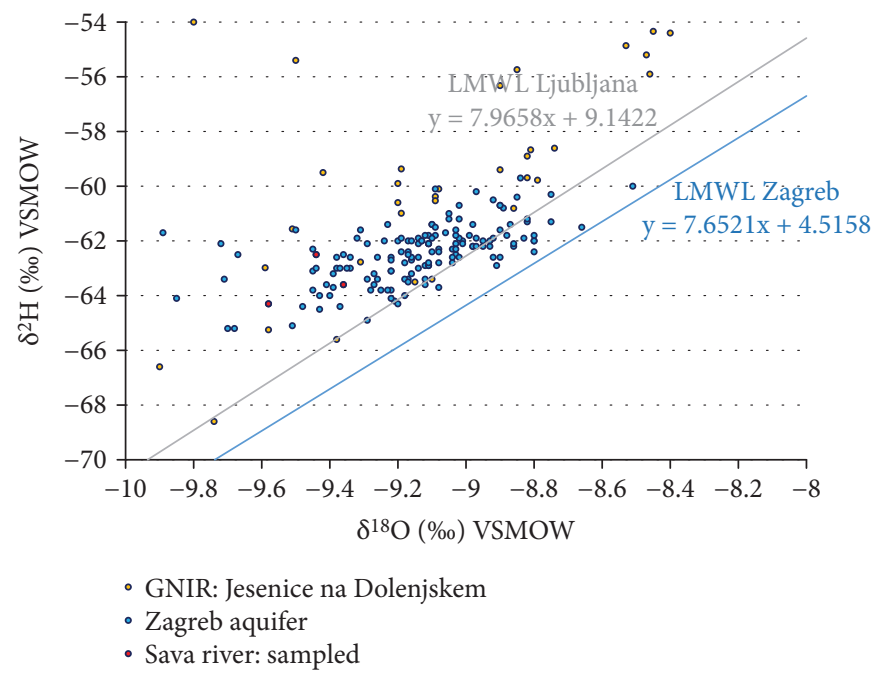

FIGURE 4: Water stable isotope composition.

area, while the other is located on the right bank of the Sava River, in the dominantly agricultural and rural area. Lower nitrate concentrations are observed near the Sava River and in the eastern part of the aquifer, where aquifer thickness increases [10,12]. Considering potential sources of contamination, it can be assumed that on the left bank of the Sava River, urban sources prevail, while on the right bank, a mix of different contamination sources is present. From land cover [48], location of farms, and spatial distribution of the sewage network (see Figure 2), it can be seen that most of the farms and agricultural areas are located on the right bank of the Sava River. Nitrate contamination in the urban part of the City of Zagreb is mostly related to leaching from the permeable sewage network and/or septic tanks.

\section{Materials and Methods}

In this research, two data sets were used. The first data set is based on all available groundwater chemistry data from the national monitoring programme of Croatian Waters and from the monitoring programme of the Jakuševec landfill. Data from 1991 until the end of 2015 was used, in sum more than 16,000 chemical analyses from 153 observation wells. Observation wells have different sampling intervals, from monthly to yearly, and different chemical parameters have been measured. Considering the above, it was decided that only major ions and most frequently measured chemical parameters, in sum 13 chemical parameters (average values), will be used for the evaluation of groundwater chemistry of the Zagreb aquifer (groundwater temperature, $\mathrm{pH}$, oxidation-reduction potential (ORP), electrical conductivity (EC), dissolved oxygen $\left(\mathrm{O}_{2}\right), \mathrm{NO}_{3}{ }^{-}, \mathrm{Cl}^{-}, \mathrm{SO}_{4}{ }^{2-}, \mathrm{HCO}_{3}{ }^{-}$, $\mathrm{Ca}^{2+}, \mathrm{Mg}^{2+}, \mathrm{Na}^{+}$, and $\mathrm{K}^{+}$). Concentrations of $\mathrm{NH}_{4}^{+}$and $\mathrm{NO}_{2}{ }^{-}$were not included in the analysis due to very rare occurrence of these nitrogen species, in sum about $4 \%$ of all analysis [10].

The second data set is represented by groundwater and river samples, which were sampled for determining the nitrate origin during one hydrologic year. The data set consists of 12 chemical parameters (groundwater temperature, $\mathrm{pH}$, oxidation-reduction potential (ORP), electrical conductivity (EC), $\mathrm{NO}_{3}{ }^{-}, \mathrm{Cl}^{-}, \mathrm{SO}_{4}{ }^{2-}, \mathrm{HCO}_{3}{ }^{-}, \mathrm{Ca}^{2+}, \mathrm{Mg}^{2+}$, $\mathrm{Na}^{+}$, and $\mathrm{K}^{+}$). Concentrations of $\mathrm{NO}_{2}{ }^{-}$were determined in two samples and $\mathrm{NH}_{4}{ }^{+}$in three samples and were not used in further analysis. Groundwater sampling was carried out in two phases and two areas. Areas were determined based on the results from previous research related to definition of spatial and temporal distribution of highest nitrate concentrations $[10,12]$. One area is located on the left part of the Sava River bank and the other on the right bank (see Figure 3). Preliminary sampling was done at 56 observation wells from the end of year 2015 (November and December) to the beginning of the year 2016 (January).

Results of nitrate stable isotope composition conducted in the first phase were used to define locations and frequency of sampling in the year 2016. First results did not show many deviations in isotopic composition, so the main criteria for the determination of observation wells which were sampled in the next phase were nitrate concentration and their location. Finally, 30 observation wells (see Figure 3) were chosen for sampling in the second phase, while three samples from the Sava River were provided by the Ruđer Bošković Institute. In total, 149 samples were taken and processed. For nitrate stable isotope analysis, samples were filtered on field and placed into HDPE Nalgene bottles.

Nitrate stable isotope composition, i.e., $\delta^{15} \mathrm{~N}_{-} \mathrm{NO}_{3}{ }^{-}$and $\delta^{18} \mathrm{O}-\mathrm{NO}_{3}{ }^{-}$, was determined by the Isotope Science Laboratory at the University of Calgary (Alberta, Canada) using a mass spectrometer (DeltaV+PreCon+ConfloIV) and denitrifier technique [17] with uncertainty of $\pm 0.3 \%$ for $\delta^{15} \mathrm{~N}$ and $\pm 0.7 \%$ for $\delta^{18} \mathrm{O}$. Water stable isotope composition $\left(\delta^{2} \mathrm{H}\right.$ $\mathrm{H}_{2} \mathrm{O}$ and $\delta^{18} \mathrm{O}-\mathrm{H}_{2} \mathrm{O}$ ), as well as all other analyses, was determined by the Faculty of Mining, Geology and Petroleum Engineering at the University of Zagreb (laboratory for spectroscopy), using a Liquid Water Isotope Analyzer (LWIA-45-EP) by Los Gatos Research Inc., with uncertainty of $\pm 0.16 \%$ for $\delta^{2} \mathrm{H}$ and $\pm 0.1 \%$ for $\delta^{18} \mathrm{O}$. All values are reported in the usual delta notation as permil relative to 


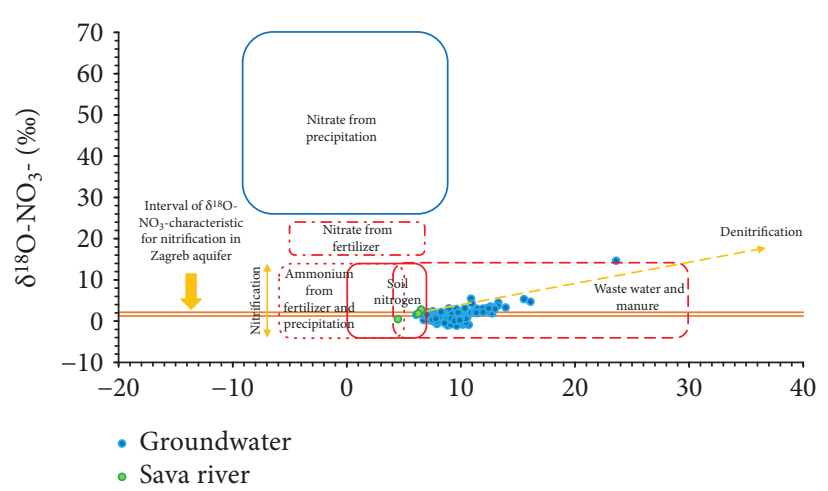

(a)

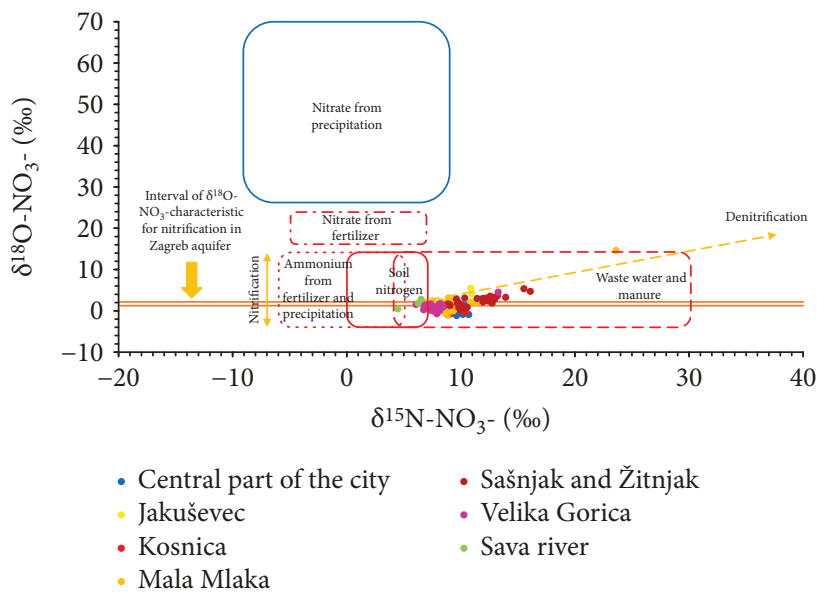

(c)

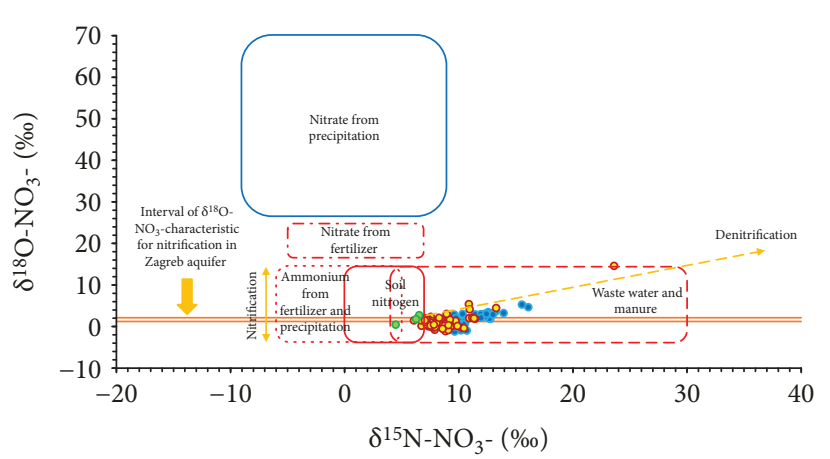

- Left bank

- Right bank

- Sava river

(b)

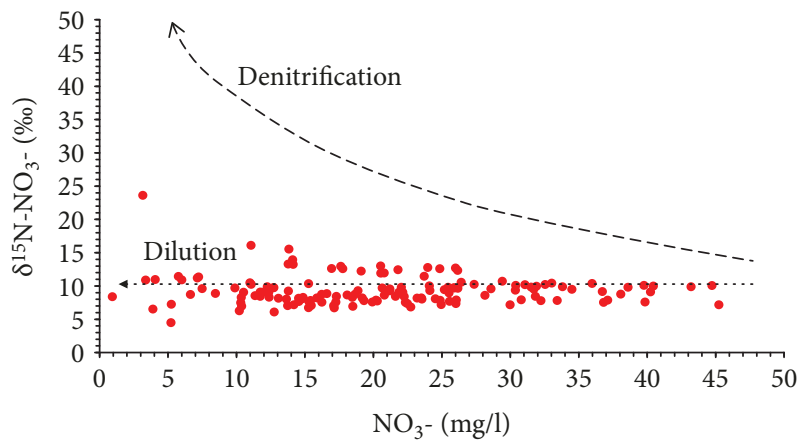

Figure 5: Values of nitrate stable isotope composition: (a) at the level of the whole Zagreb aquifer; (b) at the level of the left and right Sava River banks; (c) at the level of the spatially grouped observation wells; (d) evaluation of the process of denitrification.

AIR and VSMOW (Vienna Standard Mean Ocean Water). Water stable isotopes were used for testing the water origin, while $\delta^{18} \mathrm{O}-\mathrm{H}_{2} \mathrm{O}$ values were additionally used for the estimation of the interval characteristic for nitrates derived from nitrification [5, 24, 49], where a value of $+23.5 \%$ was used for $\delta^{18} \mathrm{O}-\mathrm{O}_{2}$ [49]. In that sense, they were compared to all available data for the Zagreb, Ljubljana, and Jesenice na Dolenjskem stations, from GNIP and GNIR (Global Networks of Isotopes in Precipitation and Rivers) within the WISER (Water Isotope System for Data Visualization, Analysis and Electronic Retrieval) database [50]. A laboratory information management system (LIMS) [51] was used for the preparation, processing, and data interpretation. Major ions were determined by Ion Chromatography System (ICS-90), while for hydrogencarbonate determination, titration was used. EC was measured by instrument "Cond 3110" (WTW company), while $\mathrm{pH}$, ORP, and groundwater temperature were measured using instrument "pH 315" (WTW company) and $\mathrm{pH} / \mathrm{ORP}$ tester (Hanna instruments).

Average molar ratios of $\mathrm{NO}_{3}{ }^{-} / \mathrm{Cl}^{-}, \mathrm{NO}_{3}{ }^{-} / \mathrm{Na}^{+}$, and $\mathrm{NO}_{3}{ }^{-} / \mathrm{K}^{+}$were calculated for each observation well for both data sets and used for the estimation of the molar ratio slope in the spatially grouped observation wells, which in most cases coincide with the well field's inflow areas (Sašnjak and Žitnjak, Petruševec, Ivanja Reka, Mala Mlaka, Velika Gorica, Zapruđe, and Kosnica; see Figure 1). The same spatial analogy was used in the interpretation of nitrate stable isotope composition.

Statistical analyses were made in Statistica 64 [52]. Normal distribution of all parameters from the first and second data sets was tested using the Kolmogorov-Smirnov test. Pearson and Spearman correlation coefficients were used to test correlation between all used parameters before usage of multivariate statistical analyses. Principal component analysis (PCA; default extraction method under factor analysis in Statistica 64) was used to extract parameters that are related to anthropogenic influence, which were then used in cluster analysis, in combination with nitrate stable isotopes and ion molar ratios, to identify nitrate origin at selected observation wells. Varimax rotation was used for the interpretation of final principal components (PC), while loadings higher than 0.6 were selected as significant, which is consistent with guidelines provided in statistical literature 




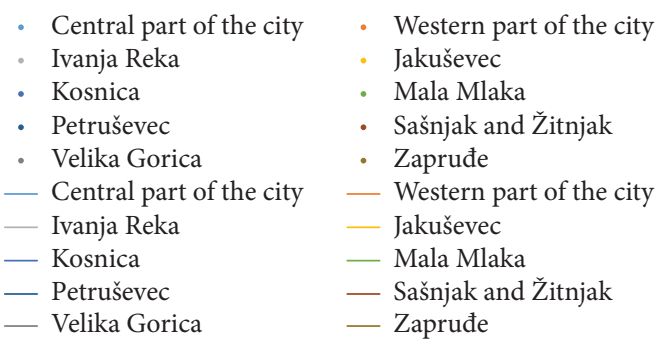

(a)

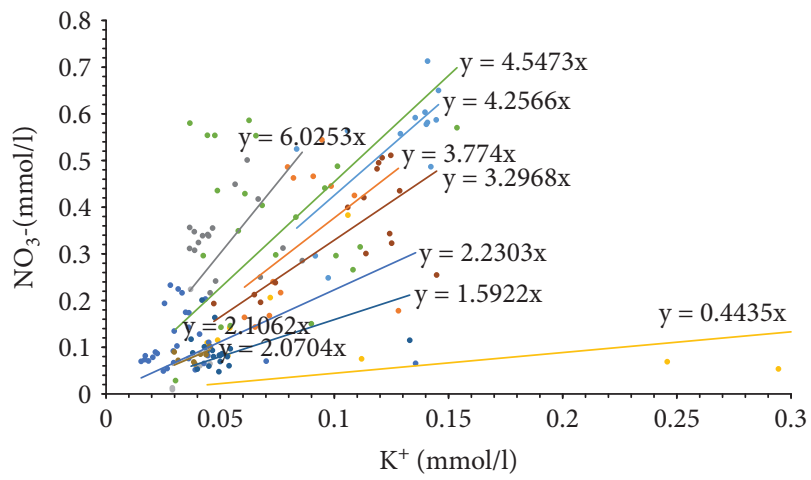

- Central part of the city

- Ivanja Reka

- Kosnica

- Petruševec

- Velika Gorica

- Central part of the city

- Ivanja Reka

- Kosnica

— Petruševec

_ Velika Gorica

- Mala Mlak

- Sašnjak and Žitnjak

- Zapruđe

_ Western part of the city

_ Jakuševec

- Mala Mlaka

_ Sašnjak and Žitnjak

— Zapruđe



- Central part of the city Ivanja Reka

- Kosnica

- Petruševec

- Velika Gorica

- Central part of the city

_ Ivanja Reka

- Kosnica

_ Petruševec

_ Velika Gorica

- Western part of the city

- Jakuševec

- Mala Mlaka

- Sašnjak and Žitnjak

- Zapruđe

- Western part of the city

- Jakuševec

- Mala Mlaka

_ Sašnjak and Žitnjak

- Zapruđe

(b)

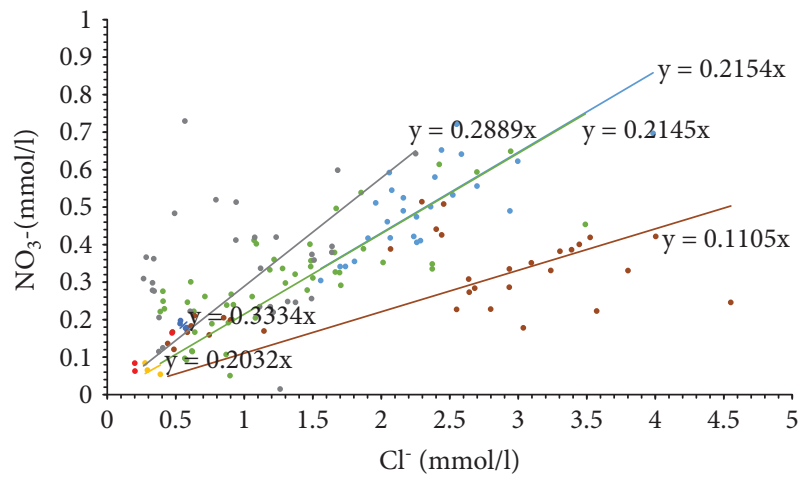

- Central part of the city - Western part of the city

- Ivanja Reka

- Kosnica

Jakuševec

- Petruševec

Velika Gorica

- Mala Mlaka
- Central part of the city

- Ivanja Reka

- Kosnica

- Petruševec

_ Velika Gorica
- Sašnjak and Žitnjak

- Zapruđe

- Western part of the city

- Jakuševec

- Mala Mlaka

_ Sašnjak and Žitnjak

— Zapruđe

(d)

Figure 6: Continued. 



\begin{tabular}{|c|c|}
\hline Central part of the city & - Western part of the city \\
\hline Ivanja Reka & - Jakuševec \\
\hline Kosnica & - Mala Mlaka \\
\hline Petruševec & - Sašnjak and Žitnjak \\
\hline Velika Gorica & - Zapruđe \\
\hline Central part of the city & — Western part of the city \\
\hline Ivanja Reka & — Jakuševec \\
\hline Kosnica & _ Mala Mlaka \\
\hline Petruševec & — Sašnjak and Žitnjak \\
\hline Velika Gorica & — Zapruđe \\
\hline
\end{tabular}

(e)

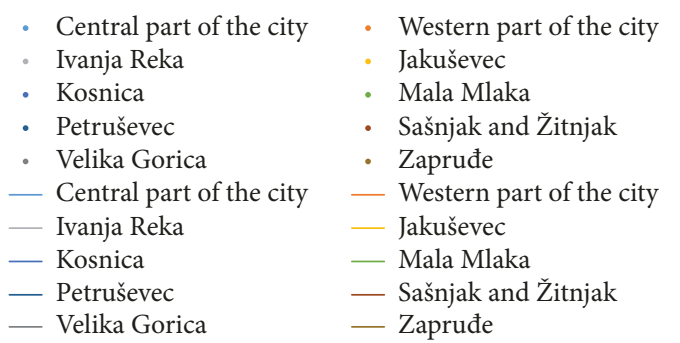

(f)

Figure 6: Molar ratios of (a) nitrates and chlorides in the historical data set, (b) nitrates and sodium in the historical data set, (c) nitrates and potassium in the historical data set, (d) nitrates and chlorides in the sampled water, (e) nitrates and sodium in the sampled water, and (f) nitrates and potassium in the sampled water.

[53], with regard to the number of data and desired statistical significance $(\alpha=0.05)$. Although there are different rules of thumb considering usage of minimum data in factor analysis, a minimum requirement of 100 cases [54], and a $5: 1$ case-to-variable ratio [53], was satisfied. Cluster analysis was conducted using Ward's method and squared Euclidean distances. Due to different measure units of selected parameters, all data was standardized to $Z$ values. All maps were made in ArcMap 10.1, while a georeferenced orthophoto image was obtained from the geoportal of the Croatian Geodetic Administration. All maps are presented in the official coordinate system of the Republic of Croatia (HTRS96/TM).

\section{Results and Discussion}

Water isotopic composition showed that groundwater from the Zagreb aquifer system is isotopically most similar to water from the Sava river at the "Jesenice na Dolenjskem" station, located at the Slovenian-Croatian border, and to precipitation from the City of Ljubljana (Local Meteoric Water Line (LMWL) Ljubljana). Isotopic composition of groundwater is less similar to precipitation from the City of Zagreb (LMWL Zagreb, see Figure 4). This is consistent with previous researches $[11,55]$. Values of $\delta^{18} \mathrm{O}-\mathrm{H}_{2} \mathrm{O}$ generally vary from -9.89 to $-8.51 \%$ and were used for the estimation of interval characteristic for nitrification (see Figure 5), ranging from +1.24 to $+2.16 \%$ of $\delta^{18} \mathrm{O}-\mathrm{NO}_{3}{ }^{-}$. Nitrate stable isotopes showed that nitrates in groundwater of the Zagreb aquifer system are mostly related to an input of anthropogenic organic matter (derived from manure and/or waste water, see Figure 5(a)), while synthetic fertilizers were excluded as the main source of nitrate contamination. In Figure 5(a), it can also be seen that nitrates are not related to nitrates from precipitation, which agrees with the fact that groundwater isotopic composition is less associated with precipitation that falls in the area of the Zagreb aquifer system. Nitrate stable isotopes, measured in the samples from the Sava River, have very similar isotopic composition as those from groundwater, which confirms the existing stream-aquifer relationship. Values of

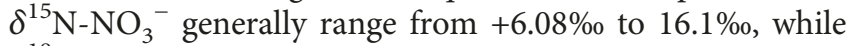
$\delta^{18} \mathrm{O}-\mathrm{NO}_{3}{ }^{-}$values range from $-1.16 \%$ o up to $+5.44 \%$, with one sample being excluded from further data processing, which was considered to be subject of subsequent denitrification. Nitrate stable isotopes were also evaluated at the level of two Sava River banks (see Figure 5(b)). It can been seen that values from the right bank are slightly more enriched in $\delta^{15} \mathrm{~N}-\mathrm{NO}_{3}{ }^{-}$and $\delta^{18} \mathrm{O}-\mathrm{NO}_{3}{ }^{-}$values. If that is evaluated at the level of spatially grouped observation wells (see Figure 5(c)), it can be seen that enriched values are mostly related to the groundwater from the Sašnjak-Žitnjak area. If the importance of the denitrification process on nitrate concentrations is considered, it can been seen that its influence is negligible (see Figure 5(d)), except in maybe the Sašnjak-Žitnjak area. On the other hand, most of the samples fall near the estimated interval of $\delta^{18} \mathrm{O}-\mathrm{NO}_{3}{ }^{-}$ values characteristic for the process of nitrification.

Average molar ratios of $\mathrm{NO}_{3}{ }^{-} / \mathrm{Cl}^{-}, \mathrm{NO}_{3}{ }^{-} / \mathrm{Na}^{+}$, and $\mathrm{NO}_{3}{ }^{-} / \mathrm{K}^{+}$and their slope lines were spatially grouped and evaluated based on the data from historical analysis (see Figures 6(a)-6(c)) and the data from sampled water (see Figures 6(d)-6(f)). When considering calculated molar ratios, based both on historical and sampled data, the most important thing which can be seen is that molar ratios from 
TABle 1: Correlation result matrices (statistically significant correlation coefficients are marked in italics): (a) Pearson coefficients on historical groundwater analysis, (b) Spearman coefficients on historical groundwater analysis, (c) Pearson coefficients on sampled water, and (d) Spearman coefficients on sampled water.

(a)

\begin{tabular}{|c|c|c|c|c|c|c|c|c|c|c|c|c|c|}
\hline Parameter & Water temperature & $\mathrm{pH}$ & ORP & $\mathrm{O}_{2}$ & $\mathrm{NO}_{3}^{-}$ & $\mathrm{Ca}^{2+}$ & $\mathrm{Mg}^{2+}$ & $\mathrm{Na}^{+}$ & $\mathrm{K}^{+}$ & $\mathrm{Cl}^{-}$ & $\mathrm{SO}_{4}{ }^{2-}$ & $\mathrm{HCO}_{3}^{-}$ & EC \\
\hline Water temperature & 1.00 & & & & & & & & & & & & \\
\hline $\mathrm{pH}$ & -0.21 & 1.00 & & & & & & & & & & & \\
\hline ORP & -0.15 & 0.24 & 1.00 & & & & & & & & & & \\
\hline $\mathrm{O}_{2}$ & -0.19 & -0.64 & -0.05 & 1.00 & & & & & & & & & \\
\hline $\mathrm{NO}_{3}^{-}$ & 0.11 & -0.77 & -0.13 & 0.75 & 1.00 & & & & & & & & \\
\hline $\mathrm{Ca}^{2+}$ & 0.13 & -0.90 & -0.23 & 0.55 & 0.77 & 1.00 & & & & & & & \\
\hline $\mathrm{Mg}^{2+}$ & 0.09 & -0.77 & -0.21 & 0.48 & 0.74 & 0.85 & 1.00 & & & & & & \\
\hline $\mathrm{Na}^{+}$ & 0.49 & -0.79 & -0.25 & 0.33 & 0.64 & 0.78 & 0.63 & 1.00 & & & & & \\
\hline $\mathrm{K}^{+}$ & 0.46 & -0.54 & -0.17 & 0.17 & 0.35 & 0.37 & 0.25 & 0.66 & 1.00 & & & & \\
\hline $\mathrm{Cl}^{-}$ & 0.40 & -0.69 & -0.20 & 0.30 & 0.59 & 0.75 & 0.61 & 0.90 & 0.49 & 1.00 & & & \\
\hline $\mathrm{SO}_{4}^{2-}$ & 0.37 & -0.77 & -0.23 & 0.22 & 0.58 & 0.80 & 0.74 & 0.80 & 0.51 & 0.74 & 1.00 & & \\
\hline $\mathrm{HCO}_{3}^{-}$ & 0.12 & -0.91 & -0.23 & 0.56 & 0.70 & 0.93 & 0.80 & 0.69 & 0.49 & 0.65 & 0.75 & 1.00 & \\
\hline $\mathrm{EC}$ & 0.26 & -0.95 & -0.28 & 0.57 & 0.79 & 0.94 & 0.81 & 0.88 & 0.56 & 0.84 & 0.85 & 0.92 & 1.00 \\
\hline
\end{tabular}

(b)

\begin{tabular}{|c|c|c|c|c|c|c|c|c|c|c|c|c|c|}
\hline Parameter & Water temperature & $\mathrm{pH}$ & ORP & $\mathrm{O}_{2}$ & $\mathrm{NO}_{3}^{-}$ & $\mathrm{Ca}^{2+}$ & $\mathrm{Mg}^{2+}$ & $\mathrm{Na}^{+}$ & $\mathrm{K}^{+}$ & $\mathrm{Cl}^{-}$ & $\mathrm{SO}_{4}{ }^{2-}$ & $\mathrm{HCO}_{3}^{-}$ & $\mathrm{EC}$ \\
\hline Water temperature & 1.00 & & & & & & & & & & & & \\
\hline $\mathrm{pH}$ & -0.21 & 1.00 & & & & & & & & & & & \\
\hline ORP & -0.15 & 0.24 & 1.00 & & & & & & & & & & \\
\hline $\mathrm{O}_{2}$ & -0.19 & -0.64 & -0.02 & 1.00 & & & & & & & & & \\
\hline $\mathrm{NO}_{3}^{-}$ & 0.02 & -0.78 & -0.07 & 0.78 & 1.00 & & & & & & & & \\
\hline $\mathrm{Ca}^{2+}$ & 0.12 & -0.91 & -0.22 & 0.56 & 0.76 & 1.00 & & & & & & & \\
\hline $\mathrm{Mg}^{2+}$ & 0.02 & -0.79 & -0.24 & 0.50 & 0.73 & 0.86 & 1.00 & & & & & & \\
\hline $\mathrm{Na}^{+}$ & 0.44 & -0.87 & -0.31 & 0.50 & 0.65 & 0.81 & 0.64 & 1.00 & & & & & \\
\hline $\mathrm{K}^{+}$ & 0.47 & -0.76 & -0.16 & 0.40 & 0.55 & 0.60 & 0.48 & 0.83 & 1.00 & & & & \\
\hline $\mathrm{Cl}^{-}$ & 0.35 & -0.87 & -0.25 & 0.62 & 0.76 & 0.83 & 0.67 & 0.93 & 0.73 & 1.00 & & & \\
\hline $\mathrm{SO}_{4}{ }^{2-}$ & 0.23 & -0.86 & -0.24 & 0.44 & 0.63 & 0.84 & 0.72 & 0.79 & 0.69 & 0.80 & 1.00 & & \\
\hline $\mathrm{HCO}_{3}^{-}$ & 0.12 & -0.92 & -0.21 & 0.54 & 0.69 & 0.94 & 0.80 & 0.77 & 0.62 & 0.79 & 0.84 & 1.00 & \\
\hline EC & 0.22 & -0.97 & -0.27 & 0.62 & 0.80 & 0.94 & 0.80 & 0.89 & 0.73 & 0.92 & 0.89 & 0.93 & 1.00 \\
\hline
\end{tabular}

(c)

\begin{tabular}{|c|c|c|c|c|c|c|c|c|c|c|c|c|}
\hline Parameter & Water temperature & $\mathrm{pH}$ & ORP & $\mathrm{NO}_{3}^{-}$ & $\mathrm{Ca}^{2+}$ & $\mathrm{Mg}^{2+}$ & $\mathrm{Na}^{+}$ & $\mathrm{K}^{+}$ & $\mathrm{Cl}^{-}$ & $\mathrm{SO}_{4}{ }^{2-}$ & $\mathrm{HCO}_{3}^{-}$ & $\mathrm{EC}$ \\
\hline Water temperature & 1.00 & & & & & & & & & & & \\
\hline $\mathrm{pH}$ & -0.23 & 1.00 & & & & & & & & & & \\
\hline ORP & -0.13 & 0.15 & 1.00 & & & & & & & & & \\
\hline $\mathrm{NO}_{3}^{-}$ & 0.34 & -0.40 & -0.03 & 1.00 & & & & & & & & \\
\hline $\mathrm{Ca}^{2+}$ & 0.47 & -0.48 & 0.17 & 0.53 & 1.00 & & & & & & & \\
\hline $\mathrm{Mg}^{2+}$ & 0.36 & -0.42 & 0.18 & 0.57 & 0.91 & 1.00 & & & & & & \\
\hline $\mathrm{Na}^{+}$ & 0.57 & -0.41 & 0.13 & 0.40 & 0.83 & 0.73 & 1.00 & & & & & \\
\hline $\mathrm{K}^{+}$ & 0.57 & -0.11 & 0.12 & 0.24 & 0.65 & 0.55 & 0.73 & 1.00 & & & & \\
\hline $\mathrm{Cl}^{-}$ & 0.59 & -0.48 & -0.05 & 0.55 & 0.82 & 0.74 & 0.90 & 0.65 & 1.00 & & & \\
\hline $\mathrm{SO}_{4}{ }^{2-}$ & 0.68 & -0.36 & -0.15 & 0.46 & 0.78 & 0.68 & 0.77 & 0.64 & 0.86 & 1.00 & & \\
\hline $\mathrm{HCO}_{3}^{-}$ & 0.27 & -0.30 & 0.36 & 0.47 & 0.87 & 0.85 & 0.70 & 0.56 & 0.62 & 0.58 & 1.00 & \\
\hline $\mathrm{EC}$ & 0.55 & -0.52 & 0.11 & 0.54 & 0.96 & 0.88 & 0.91 & 0.69 & 0.90 & 0.84 & 0.84 & 1.00 \\
\hline
\end{tabular}


(d)

\begin{tabular}{|c|c|c|c|c|c|c|c|c|c|c|c|c|}
\hline Parameter & Water temperature & $\mathrm{pH}$ & ORP & $\mathrm{NO}_{3}^{-}$ & $\mathrm{Ca}^{2+}$ & $\mathrm{Mg}^{2+}$ & $\mathrm{Na}^{+}$ & $\mathrm{K}^{+}$ & $\mathrm{Cl}^{-}$ & $\mathrm{SO}_{4}^{2-}$ & $\mathrm{HCO}_{3}^{-}$ & EC \\
\hline Water temperature & 1.00 & & & & & & & & & & & \\
\hline $\mathrm{pH}$ & -0.26 & 1.00 & & & & & & & & & & \\
\hline ORP & -0.17 & 0.23 & 1.00 & & & & & & & & & \\
\hline $\mathrm{NO}_{3}^{-}$ & 0.34 & -0.37 & -0.05 & 1.00 & & & & & & & & \\
\hline $\mathrm{Ca}^{2+}$ & 0.55 & -0.46 & 0.12 & 0.58 & 1.00 & & & & & & & \\
\hline $\mathrm{Mg}^{2+}$ & 0.40 & -0.42 & 0.07 & 0.60 & 0.93 & 1.00 & & & & & & \\
\hline $\mathrm{Na}^{+}$ & 0.63 & -0.43 & 0.07 & 0.43 & 0.84 & 0.75 & 1.00 & & & & & \\
\hline $\mathrm{K}^{+}$ & 0.59 & -0.16 & 0.12 & 0.25 & 0.67 & 0.55 & 0.75 & 1.00 & & & & \\
\hline $\mathrm{Cl}^{-}$ & 0.64 & -0.53 & -0.08 & 0.61 & 0.86 & 0.79 & 0.90 & 0.67 & 1.00 & & & \\
\hline $\mathrm{SO}_{4}^{2-}$ & 0.70 & -0.40 & -0.22 & 0.54 & 0.81 & 0.72 & 0.78 & 0.66 & 0.88 & 1.00 & & \\
\hline $\mathrm{HCO}_{3}^{-}$ & 0.35 & -0.22 & 0.33 & 0.49 & 0.84 & 0.81 & 0.72 & 0.55 & 0.68 & 0.63 & 1.00 & \\
\hline $\mathrm{EC}$ & 0.61 & -0.52 & 0.07 & 0.59 & 0.96 & 0.88 & 0.91 & 0.69 & 0.92 & 0.83 & 0.84 & 1.00 \\
\hline
\end{tabular}

TABLE 2: Results of PCA (significant loadings are marked in italics).

\begin{tabular}{lcccc}
\hline \multirow{2}{*}{ Parameter } & \multicolumn{2}{c}{$\begin{array}{c}\text { Historical } \\
\text { groundwater } \\
\text { analysis }\end{array}$} & \multicolumn{2}{c}{ Sampled water } \\
& PC 1 & PC 2 & PC 1 & PC 2 \\
\hline Water temperature & -0.08 & 0.85 & 0.11 & 0.88 \\
$\mathrm{O}_{2}$ & 0.78 & -0.30 & - & - \\
$\mathrm{NO}_{3}{ }^{-}$ & 0.88 & 0.08 & 0.67 & 0.11 \\
$\mathrm{Ca}^{2+}$ & 0.92 & 0.25 & 0.87 & 0.43 \\
$\mathrm{Mg}^{2+}$ & 0.87 & 0.15 & 0.91 & 0.27 \\
$\mathrm{Na}^{+}$ & 0.66 & 0.68 & 0.64 & 0.67 \\
$\mathrm{~K}^{+}$ & 0.30 & 0.70 & 0.38 & 0.73 \\
$\mathrm{Cl}^{-}$ & 0.65 & 0.60 & 0.65 & 0.66 \\
$\mathrm{SO}_{4}{ }^{2-}$ & 0.68 & 0.57 & 0.54 & 0.73 \\
$\mathrm{HCO}_{3}^{-}$ & 0.89 & 0.25 & 0.90 & 0.19 \\
$\mathrm{EC}^{-}$ & 0.90 & 0.42 & 0.82 & 0.55 \\
\hline
\end{tabular}

the central part of the City of Zagreb are most similar to those from the Mala Mlaka and Velika Gorica areas, which are located in the mainly agricultural and rural area. These results indicate that there is a very similar dominant source of nitrate contamination in the both the left and right Sava River banks.

The Kolmogorov-Smirnov test showed that in general, average values calculated from historical data did not satisfy the condition of normal distribution, while those from sampled water did. However, the correlation analysis showed very similar results on both data sets and with both correlation coefficients (see Table 1, marked in italics are statistically significant correlation coefficients). When evaluating both data sets, it can be seen that almost all parameters are well positively correlated, except $\mathrm{pH}$ and ORP. Generally, ORP does not show any significant correlation with other parameters, while $\mathrm{pH}$ shows negative correlation with almost all parameters. Hence, $\mathrm{pH}$ and ORP were excluded from the multivariate statistical analysis. Correlation results suggest that microbial oxidation of ammonium causes acidity along with nitrates in soils, which can be buffered by the dissolution of a carbonate aquifer matrix [56]. Also, it has been shown that in aquifers with different lithological composition, nitrates can have effect on the biogeochemical processes that influence water-rock interactions [57], which can in the end lead to an overall increase in mineralization [58].

The results of PCA are shown in Table 2. Both analyses resulted in two principal components, with about $80 \%$ of explained variance. In the data set related to historical analysis, $64.3 \%$ and $15.4 \%$ of variance were explained by PC 1 and PC 2, respectively, while in the data set related to sampled water, $70.77 \%$ and $10.43 \%$ of variance were explained by PC 1 and PC 2, respectively. It can be seen that results obtained with both data sets are very similar. In both cases, groundwater temperature and $\mathrm{K}^{+}$concentration are not significant in PC 1 but are significant in PC 2. Also, in the PCA related to historical analysis, loading of $\mathrm{SO}_{4}{ }^{2-}$ concentration is significant in PC 2 and very close to threshold loading in PC 2, while in the case of the sampled water, loading is significant only in $\mathrm{PC} 2$. In addition, $\mathrm{Cl}^{-}$and $\mathrm{Na}^{+}$concentrations are significant in PC 1 and PC 2, while $\mathrm{NO}_{3}{ }^{-}$concentration is only significant in $\mathrm{PC}$ 1. All results suggest that primary indicators of anthropogenic influence are separated in PC $2\left(\mathrm{Na}^{+}, \mathrm{K}^{+}\right.$, $\mathrm{Cl}^{-}$, and $\mathrm{SO}_{4}{ }^{2-}$ ), even though part of their concentrations are also the consequence of natural processes that take place in the Zagreb aquifer system. Results of PCA suggest that $\mathrm{NO}_{3}{ }^{-}$concentrations are more related to natural processes, due to existence of dominantly aerobic conditions in the most of the Zagreb aquifer. Although nitrates originate in groundwater from waste water and/or manure, a large part of nitrogen is introduced into the aquifer in the form of $\mathrm{NH}_{4}{ }^{+}$and consequently transformed to $\mathrm{NO}_{3}{ }^{-}$due to the presence of dissolved oxygen concentrations and associated nitrification.

Based on the results of PCA analysis, for the purpose of defining the nitrate origin on each observation well, average concentrations of $\mathrm{NO}_{3}{ }^{-}, \mathrm{Cl}^{-}, \mathrm{SO}_{4}{ }^{2-}, \mathrm{Na}^{+}$, and $\mathrm{K}^{+}$, average values of stable nitrate isotope composition, and the average molar ratios of $\mathrm{NO}_{3}{ }^{-}$to $\mathrm{Cl}^{-}, \mathrm{SO}_{4}{ }^{2-}, \mathrm{Na}^{+}$, and $\mathrm{K}^{+}$were used (see Table 3). Only observation wells from which groundwater was sampled in time were considered in this analysis. 
TABLE 3: Average values of parameters at observation wells.

\begin{tabular}{|c|c|c|c|c|c|c|c|c|c|c|c|}
\hline $\begin{array}{l}\text { Observation well/ } \\
\text { parameter }\end{array}$ & $\begin{array}{l}\mathrm{NO}_{3}^{-} \\
(\mathrm{mg} / \mathrm{l}) \\
\end{array}$ & $\begin{array}{c}\mathrm{Cl}^{-} \\
(\mathrm{mg} / \mathrm{l}) \\
\end{array}$ & $\begin{array}{c}\mathrm{Na}^{+} \\
(\mathrm{mg} / \mathrm{l}) \\
\end{array}$ & $\begin{array}{c}\mathrm{K}^{+} \\
(\mathrm{mg} / \mathrm{l}) \\
\end{array}$ & $\begin{array}{l}\mathrm{SO}_{4}^{2-} \\
(\mathrm{mg} / \mathrm{l}) \\
\end{array}$ & $\begin{array}{c}\delta^{15} \mathrm{~N}^{-\mathrm{NO}_{3}}{ }^{-} \\
(\% \mathrm{o})\end{array}$ & $\begin{array}{c}\delta^{18} \mathrm{O}_{-\mathrm{NO}_{3}}^{-} \\
(\% \mathrm{\%})\end{array}$ & $\begin{array}{c}\mathrm{NO}_{3}^{-} / \\
\mathrm{Cl}^{-} \\
\end{array}$ & $\begin{array}{c}\mathrm{NO}_{3}^{-} / \\
\mathrm{Na}^{+} \\
\end{array}$ & $\begin{array}{c}\mathrm{NO}_{3}^{-} / \\
\mathrm{K}^{+} \\
\end{array}$ & $\begin{array}{l}\mathrm{NO}_{3}{ }^{-} / \\
\mathrm{SO}_{4}{ }^{2-}\end{array}$ \\
\hline A-2-1 & 11.51 & 19.69 & 5.26 & 1.34 & 18.11 & 9.92 & -0.30 & 0.34 & 0.86 & 5.32 & 0.99 \\
\hline B-15 & 32.83 & 81.88 & 37.86 & 5.25 & 52.55 & 9.62 & 0.78 & 0.24 & 0.32 & 4.66 & 0.97 \\
\hline B-5 & 30.97 & 83.84 & 38.86 & 5.22 & 49.98 & 10.33 & 0.34 & 0.21 & 0.30 & 3.76 & 0.96 \\
\hline Čp-23 & 27.52 & 45.32 & 12.72 & 1.94 & 22.77 & 7.70 & 0.10 & 0.35 & 0.80 & 9.62 & 1.87 \\
\hline D-3 & 29.08 & 81.56 & 36.02 & 5.12 & 41.32 & 9.65 & 0.07 & 0.20 & 0.29 & 3.54 & 1.08 \\
\hline D-6 & 34.99 & 97.47 & 36.93 & 5.18 & 52.42 & 9.97 & 0.38 & 0.21 & 0.35 & 4.28 & 1.03 \\
\hline Lg-1 & 27.41 & 12.92 & 7.19 & 2.13 & 15.97 & 7.39 & 1.45 & 1.20 & 1.42 & 8.37 & 2.60 \\
\hline Mm-311 & 17.71 & 26.63 & 14.84 & 2.54 & 19.68 & 8.35 & 2.13 & 0.38 & 0.44 & 4.41 & 1.38 \\
\hline Mm-319 & 25.97 & 70.44 & 28.67 & 1.84 & 24.99 & 9.02 & 0.32 & 0.22 & 0.34 & 9.84 & 1.60 \\
\hline $\mathrm{Mm}-32$ & 15.12 & 14.36 & 4.15 & 1.22 & 12.39 & 7.08 & 1.61 & 0.60 & 1.53 & 7.98 & 1.89 \\
\hline $\mathrm{Mm}-320$ & 24.08 & 64.14 & 31.33 & 3.99 & 22.16 & 7.66 & 0.20 & 0.21 & 0.28 & 3.83 & 1.66 \\
\hline Mm-322 & 26.40 & 49.99 & 27.24 & 2.85 & 19.52 & 7.60 & 0.27 & 0.31 & 0.36 & 6.02 & 2.10 \\
\hline Mm-325 & 19.27 & 38.74 & 18.31 & 4.26 & 24.41 & 8.28 & -0.20 & 0.28 & 0.39 & 2.87 & 1.21 \\
\hline $\mathrm{Mm}-330$ & 13.62 & 34.24 & 19.43 & 3.09 & 28.12 & 8.51 & 2.01 & 0.23 & 0.26 & 2.87 & 0.75 \\
\hline Mm-333 & 22.96 & 84.86 & 47.04 & 5.09 & 23.28 & 8.48 & 0.24 & 0.16 & 0.18 & 2.91 & 1.54 \\
\hline Mm-49 & 24.95 & 61.83 & 28.18 & 4.66 & 29.13 & 9.04 & 0.30 & 0.23 & 0.33 & 3.61 & 1.30 \\
\hline Ph-12 & 24.61 & 72.15 & 37.07 & 5.65 & 37.54 & 9.58 & 0.01 & 0.20 & 0.25 & 2.79 & 1.02 \\
\hline Pzo-8 & 6.53 & 21.14 & 20.45 & 3.66 & 16.24 & 11.22 & 2.04 & 0.18 & 0.12 & 1.15 & 0.62 \\
\hline Sava & 6.44 & 10.37 & 6.85 & 1.62 & 12.89 & 5.76 & 1.69 & 0.36 & 0.34 & 2.43 & 0.76 \\
\hline Sk-16/2 & 20.07 & 129.35 & 55.52 & 5.67 & 61.94 & 11.68 & 2.78 & 0.09 & 0.14 & 2.24 & 0.50 \\
\hline Sk-18 & 18.87 & 98.03 & 42.17 & 5.70 & 66.93 & 12.56 & 3.19 & 0.11 & 0.17 & 2.13 & 0.44 \\
\hline $\mathrm{V}-3$ & 36.58 & 81.53 & 35.55 & 4.19 & 57.92 & 9.96 & 0.62 & 0.25 & 0.38 & 5.52 & 0.98 \\
\hline Vg-10/2 & 20.72 & 13.27 & 6.59 & 1.94 & 17.62 & 7.10 & 1.18 & 0.88 & 1.18 & 6.99 & 1.81 \\
\hline Vg-11 & 14.87 & 39.42 & 21.06 & 3.40 & 25.36 & 7.91 & 0.58 & 0.23 & 0.26 & 3.22 & 0.91 \\
\hline Vg-4 & 25.29 & 59.81 & 25.55 & 1.91 & 26.53 & 8.09 & 1.14 & 0.24 & 0.38 & 8.53 & 1.44 \\
\hline Vg-9 & 15.40 & 39.43 & 16.39 & 2.66 & 27.03 & 8.01 & 0.46 & 0.24 & 0.35 & 4.36 & 0.87 \\
\hline Z-10 & 11.13 & 29.71 & 22.40 & 2.74 & 22.51 & 9.27 & 1.59 & 0.23 & 0.22 & 2.69 & 0.78 \\
\hline Z-13 & 10.31 & 19.38 & 13.22 & 2.79 & 21.42 & 8.05 & 1.68 & 0.30 & 0.29 & 2.35 & 0.74 \\
\hline Z-4 & 22.11 & 120.24 & 48.37 & 5.29 & 76.51 & 12.40 & 2.71 & 0.10 & 0.17 & 2.66 & 0.45 \\
\hline Z-7 & 28.72 & 81.75 & 38.68 & 5.22 & 48.95 & 10.01 & 0.77 & 0.20 & 0.28 & 3.50 & 0.91 \\
\hline Ž-8 & 13.28 & 106.01 & 44.04 & 4.98 & 66.40 & 14.70 & 4.24 & 0.07 & 0.11 & 1.68 & 0.31 \\
\hline
\end{tabular}

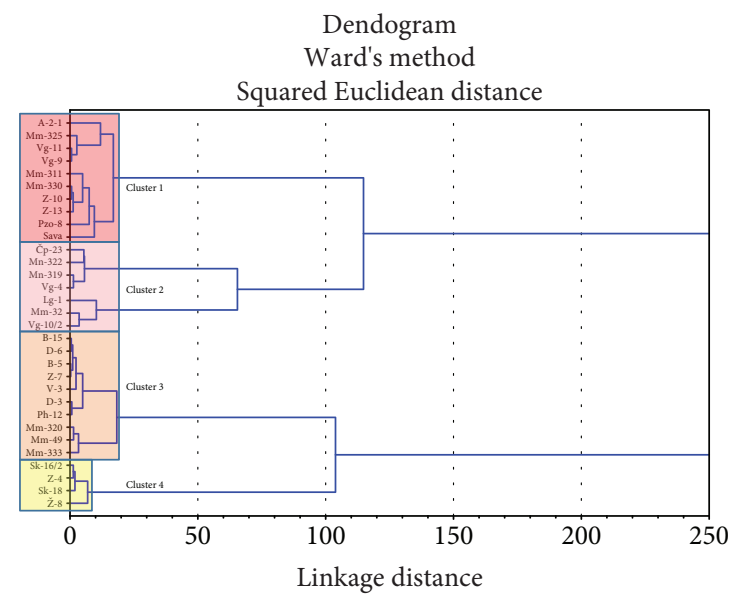

Figure 7: Results of the cluster analysis.
Cluster analysis resulted in the formation of four clusters (see Figure 7; see Table 4). If clusters are evaluated spatially (see Figure 8), it can be seen that observation wells from Clusters 1 and 3 are located both on the left and right banks of the Sava River, while observation wells from Cluster 2 are located on the right bank, and observation wells from Cluster 4 on the left bank of the Sava River. Average concentrations of $\mathrm{NO}_{3}{ }^{-}$are highest in Clusters 2 and 3 indicating two main sources of nitrate contamination (see Table 4). All other concentrations mostly increase from Cluster 1 to Cluster 4. Nitrates are isotopically enriched at the observation wells from Cluster 4, which are all located in the area of Sašnjak and Žitnjak, near the boundary of the Zagreb aquifer system where the thickness of the unsaturated zone is slightly larger and concentrations of dissolved oxygen slightly lower. In all other clusters, values of $\delta^{15} \mathrm{~N}^{-\mathrm{NO}_{3}}{ }^{-}$ and $\delta^{18} \mathrm{O}_{-} \mathrm{NO}_{3}{ }^{-}$range from +7.71 to $+9.43 \%$ and +0.37 to $+1.17 \%$, respectively. These results show how small are the 
TABLE 4: Average values of parameters in defined clusters.

\begin{tabular}{|c|c|c|c|c|c|c|c|c|c|c|c|}
\hline Cluster & $\begin{array}{l}\mathrm{NO}_{3}^{-} \\
(\mathrm{mg} / \mathrm{l})\end{array}$ & $\begin{array}{c}\mathrm{Cl}^{-} \\
(\mathrm{mg} / \mathrm{l})\end{array}$ & $\begin{array}{c}\mathrm{Na}^{+} \\
(\mathrm{mg} / \mathrm{l}) \\
\end{array}$ & $\begin{array}{c}\mathrm{K}^{+} \\
(\mathrm{mg} / \mathrm{l}) \\
\end{array}$ & $\begin{array}{l}\mathrm{SO}_{4}{ }^{2-} \\
(\mathrm{mg} / \mathrm{l})\end{array}$ & $\begin{array}{c}\delta^{15} \mathrm{~N}^{-\mathrm{NO}_{3}{ }^{-}} \\
(\% \mathrm{o})\end{array}$ & $\begin{array}{c}\delta^{18} \mathrm{O}_{-\mathrm{NO}_{3}{ }^{-}} \\
(\% \mathrm{o})\end{array}$ & $\begin{array}{c}\mathrm{NO}_{3}^{-} / \\
\mathrm{Cl}^{-}\end{array}$ & $\begin{array}{c}\mathrm{NO}_{3}{ }^{-} / \\
\mathrm{Na}^{+}\end{array}$ & $\begin{array}{c}\mathrm{NO}_{3}^{-} / \\
\mathrm{K}^{+} \\
\end{array}$ & $\begin{array}{l}\mathrm{NO}_{3}{ }^{-} \\
\mathrm{SO}_{4}{ }^{2-}\end{array}$ \\
\hline 1 & 12.68 & 27.88 & 15.82 & 2.81 & 21.58 & 8.53 & 1.17 & 0.28 & 0.35 & 3.17 & 0.90 \\
\hline 2 & 24.06 & 38.02 & 16.02 & 1.98 & 19.97 & 7.71 & 0.87 & 0.54 & 0.86 & 8.19 & 1.90 \\
\hline 3 & 28.98 & 79.10 & 36.75 & 4.96 & 41.52 & 9.43 & 0.37 & 0.21 & 0.30 & 3.84 & 1.14 \\
\hline 4 & 18.58 & 113.41 & 47.52 & 5.41 & 67.94 & 12.83 & 3.23 & 0.10 & 0.15 & 2.18 & 0.42 \\
\hline
\end{tabular}

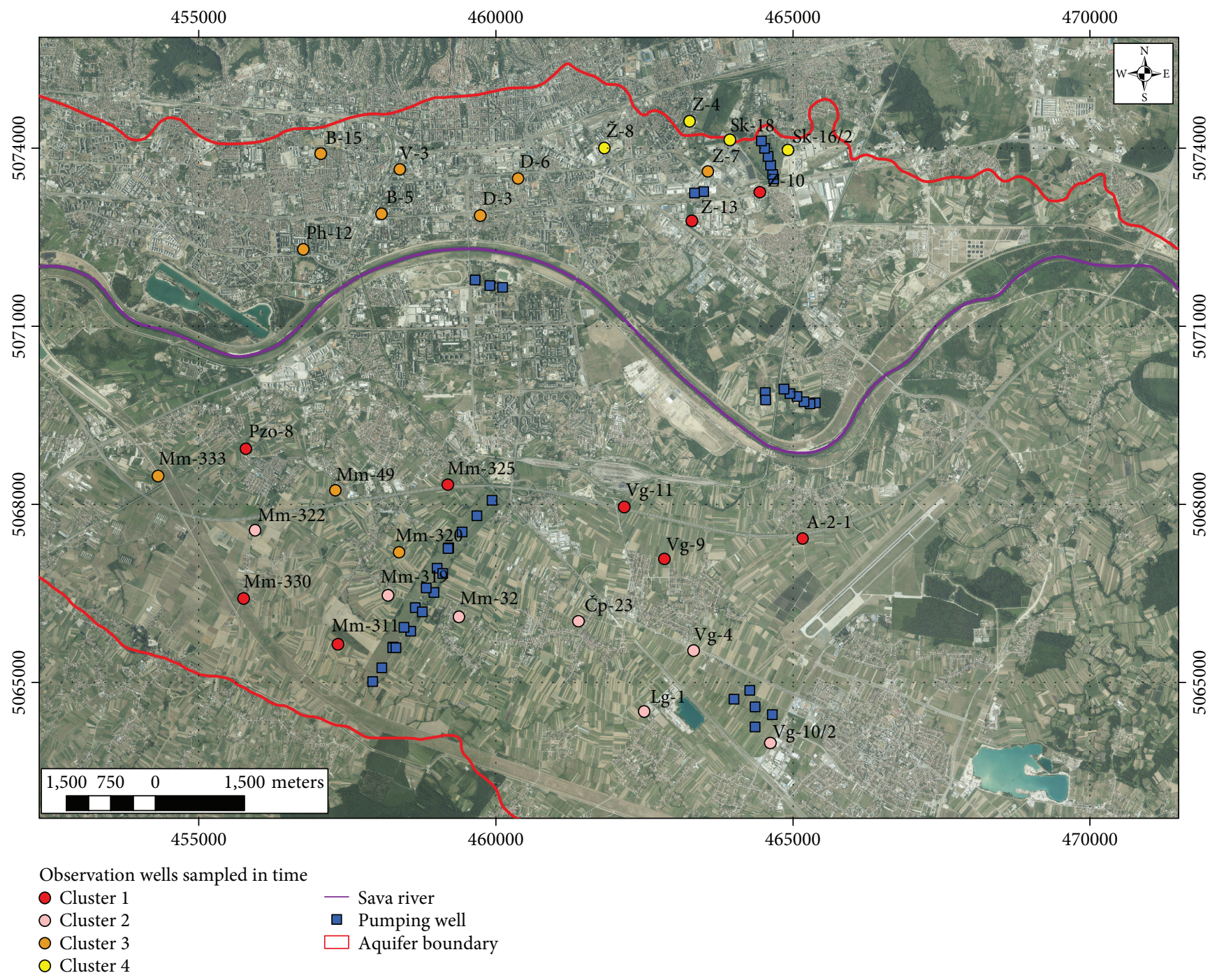

FIGURE 8: Locations of observation wells distributed within the cluster analysis.

changes in nitrate isotopic composition at selected observation wells and that in this case, they cannot be used for the identification of clusters where influence of waste water or manure prevail. However, evaluation of molar ratios, especially $\mathrm{NO}_{3}{ }^{-}$to $\mathrm{K}^{+}$, has given much clearer results. It can be seen that all values of molar ratios are highest in Cluster 2, which is most prominent when evaluating the $\mathrm{NO}_{3}{ }^{-}$to $\mathrm{K}^{+}$ molar ratio. Also, all molar ratios are very similar in the other three clusters indicating the same source of nitrate contamination. If regional groundwater flow, locations of potential contamination sources, and all presented results are taken into account, it is evident that manure presents the main source of nitrate contamination in Cluster 2. On the other side, waste water is responsible for nitrate concentrations in the other three clusters and can be defined as the main source of nitrate contamination in the Zagreb aquifer system.

\section{Conclusions}

Nitrates present one of the main contaminants in the Zagreb aquifer system, while the highest concentrations are observed 
in two areas, one dominantly urban and the other dominantly agricultural and rural. Although elevated, nitrate concentrations are below the limits of $50 \mathrm{mg} / \mathrm{N} \mathrm{NO}_{3}{ }^{-}$and have descending trends in almost all areas. The Zagreb aquifer system is declared as a vulnerable area to nitrates from agriculture as presented in the Croatian River Basin Management Plan [59], due to existence of agricultural activity, especially on the right bank of the Sava River. However, research presented in this paper has shown that nitrate concentrations are not only a consequence of agricultural inputs. Nitrate stable isotope composition excluded synthetic fertilizers as the main source of nitrate contamination. It has been observed that nitrate origin is organic. Waste water has been defined as the main source of nitrate concentrations. Nitrate isotopic composition was not able to discern which source of nitrate contamination, waste water or manure, is dominant in the particular area of the Zagreb aquifer system. In addition, nitrate stable isotope composition showed that the denitrification process is negligible in the Zagreb aquifer and that most of $\delta^{18} \mathrm{O}-\mathrm{NO}_{3}{ }^{-}$values fall into, or very near, the estimated interval characteristic for the nitrification process. Detailed inspection of groundwater chemistry, in a combination with results of multivariate statistical analysis, has resulted in a much more detailed determination of nitrate origin. Evaluation of molar ratios, especially nitrates to potassium, has proved to be crucial in nitrate source determination. It has been shown that most observation wells have detected nitrates that originate from waste water, i.e., sewage network and septic tanks. Results suggest that a large quantity of nitrogen is introduced into the aquifer in the ammonium ion form, while aerobic conditions allow nitrification to occur. All results suggest that groundwater protection measures should be more focused on the determination and repair of permeable parts of the sewage network and septic tanks, while future research should be related to detail quantification of agricultural activity on groundwater quality and biogeochemical processes, especially those that take place in the unsaturated zone.

\section{Data Availability}

Some links regarding data are listed under the reference list; part of the data is in Zoran Kovač's $\mathrm{PhD}$ thesis which will be fully publicly available in October 2019 (at this moment, it can be seen in the Library of Faculty of Mining, Geology and Petroleum Engineering and in the National and University Library in Zagreb), while the rest of the data is from the national groundwater quality monitoring programme of Croatian Waters and groundwater quality monitoring programme of the Jakuševec landfill as written in the Acknowledgments.

\section{Conflicts of Interest}

The authors declare that there are no conflicts of interest regarding the publication of this paper.

\section{Acknowledgments}

The authors would like to thank the following: (i) Croatian Waters for the data obtained from the national monitoring programme and within the project "Definition of Trends and Groundwater Status Assessment in the Pannonian Part of the Croatia"; (ii) Zagreb holding Ltd., for providing groundwater monitoring data in the area of the Jakuševec landfill; (iii) Teaching Institute of Public Health Dr. Andrija Štampar and Water Supply and Drainage Ltd., Zagreb, for the help provided for groundwater sampling; (iv) Ruđer Bošković Institute for the Sava River samples; (v) International Atomic Energy Agency for providing technical support within IAEA TC project CRO7001 ("Isotope Investigation of the Groundwater-Surface Water Interaction at the Well Field Kosnica in the Area of the City of Zagreb"); and (vi) Croatian Agricultural Agency for the provided farm location coordinates.

\section{References}

[1] M. N. Almasri, "Nitrate contamination of groundwater: a conceptual management framework," Environmental Impact Assessment Review, vol. 27, no. 3, pp. 220-242, 2007.

[2] S. Peña-Haro, M. Pulido-Velazquez, and A. Sahuquillo, "A hydro-economic modelling framework for optimal management of groundwater nitrate pollution from agriculture," Journal of Hydrology, vol. 373, no. 1-2, pp. 193-203, 2009.

[3] D. Xue, J. Botte, B. de Baets et al., "Present limitations and future prospects of stable isotope methods for nitrate source identification in surface- and groundwater," Water Research, vol. 43, no. 5, pp. 1159-1170, 2009.

[4] T. Hosono, T. Tokunaga, M. Kagabu et al., "The use of $\delta^{15} \mathrm{~N}$ and $\delta^{18} \mathrm{O}$ tracers with an understanding of groundwater flow dynamics for evaluating the origins and attenuation mechanisms of nitrate pollution," Water Research, vol. 47, no. 8, pp. 2661-2675, 2013.

[5] S. Xu, P. Kang, and Y. Sun, "A stable isotope approach and its application for identifying nitrate source and transformation process in water," Environmental Science and Pollution Research, vol. 23, no. 2, pp. 1133-1148, 2016.

[6] L. A. DeSimone and B. L. Howes, "Nitrogen transport and transformations in a shallow aquifer receiving wastewater discharge: a mass balance approach," Water Resources Research, vol. 34, no. 2, pp. 271-285, 1998.

[7] V. M. Chowdary, N. H. Rao, and P. B. S. Sarma, "Decision support framework for assessment of non-point-source pollution of groundwater in large irrigation projects," Agricultural Water Management, vol. 75, no. 3, pp. 194-225, 2005.

[8] M. A. Dimkić, H. J. Brauch, and M. Kavanaugh, Groundwater Management in Large River Basins, IWA Publishing, Alliance House, Biddles Ltd, Norfolk, UK, 2008.

[9] Z. Kovač, K. Pavlić, and Z. Nakić, "Influence of dissolved oxygen on nitrates concentration in Zagreb aquifer," in 8 th HRHU and 19th HU geomathematical congress "Geomathematics - present and future of geological modelling”, Trakošćan, Croatia, May 2016.

[10] Z. Kovač, Z. Nakić, and K. Pavlić, "Influence of groundwater quality indicators on nitrate concentrations in the Zagreb aquifer system," Geologia Croatica, vol. 70, no. 2, pp. 93-103, 2017. 
[11] Z. Nakić, S. Ružičić, K. Posavec et al., "Conceptual model for groundwater status and risk assessment-case study of the Zagreb aquifer system," Geologia Croatica, vol. 66, no. 1, pp. 55-76, 2013.

[12] Z. Kovač, M. Cvetković, and J. Parlov, "Gaussian simulation of nitrate concentration distribution in the Zagreb aquifer," Journal of Maps, vol. 13, no. 2, pp. 727-732, 2017.

[13] Z. Kovač, Z. Nakić, D. Špoljarić, D. Stanek, and A. Bačani, "Estimation of nitrate trends in the groundwater of the Zagreb aquifer," Geosciences, vol. 8, no. 5, 2018.

[14] C. C. Y. Chang, J. Langston, M. Riggs, D. H. Campbell, S. R. Silva, and C. Kendall, "A method for nitrate collection for $\delta^{15} \mathrm{~N}$ and $\delta^{18} \mathrm{O}$ analysis from waters with low nitrate concentrations," Canadian Journal of Fisheries and Aquatic Sciences, vol. 56, no. 10, pp. 1856-1864, 1999.

[15] S. R. Silva, C. Kendall, D. H. Wilkison, A. C. Ziegler, C. C. Y. Chang, and R. J. Avanzino, "A new method for collection of nitrate from fresh water and the analysis of nitrogen and oxygen isotope ratios," Journal of Hydrology, vol. 228, no. 1-2, pp. 22-36, 2000.

[16] D. M. Sigman, K. L. Casciotti, M. Andreani, C. Barford, M. Galanter, and J. K. Böhlke, "A bacterial method for the nitrogen isotopic analysis of nitrate in seawater and freshwater," Analytical Chemistry, vol. 73, no. 17, pp. 4145-4153, 2001.

[17] K. L. Casciotti, D. M. Sigman, M. G. Hastings, J. K. Böhlke, and A. Hilkert, "Measurement of the oxygen isotopic composition of nitrate in seawater and freshwater using the denitrifier method," Analytical Chemistry, vol. 74, no. 19, pp. 49054912, 2002.

[18] L. Rock and B. H. Ellert, "Nitrogen-15 and oxygen-18 natural abundance of potassium chloride extractable soil nitrate using the denitrifier method," Soil Science Society of America Journal, vol. 71, no. 2, pp. 355-361, 2007.

[19] M. R. McIlvin and M. A. Altabet, "Chemical conversion of nitrate and nitrite to nitrous oxide for nitrogen and oxygen isotopic analysis in freshwater and seawater," Analytical Chemistry, vol. 77, no. 17, pp. 5589-5595, 2005.

[20] D. H. Kohl, G. B. Shearer, and B. Commoner, "Fertilizer nitrogen: contribution to nitrate in surface water in a Corn Belt watershed," Science, vol. 174, no. 4016, pp. 1331-1334, 1971.

[21] D. Kaown, D. C. Koh, B. Mayer, and K. K. Lee, "Identification of nitrate and sulfate sources in groundwater using dual stable isotope approaches for an agricultural area with different land use (Chuncheon, mid-eastern Korea)," Agriculture, Ecosystems \& Environment, vol. 132, no. 3-4, pp. 223-231, 2009.

[22] N. Otero, C. Torrentó, A. Soler, A. Menció, and J. Mas-Pla, "Monitoring groundwater nitrate attenuation in a regional system coupling hydrogeology with multi-isotopic methods: the case of Plana de Vic (Osona, Spain)," Agriculture, Ecosystems \& Environment, vol. 133, no. 1-2, pp. 103-113, 2009.

[23] S. L. Li, C. Q. Liu, Y. C. Lang, Z. Q. Zhao, and Z. H. Zhou, "Tracing the sources of nitrate in karstic groundwater in Zunyi, Southwest China: a combined nitrogen isotope and water chemistry approach," Environmental Earth Sciences, vol. 60, no. 7, pp. 1415-1423, 2010.

[24] A. Baily, L. Rock, C. J. Watson, and O. Fenton, "Spatial and temporal variations in groundwater nitrate at an intensive dairy farm in south-east Ireland: insights from stable isotope data," Agriculture, Ecosystems \& Environment, vol. 144, no. 1, pp. 308-318, 2011.
[25] E. Sacchi, M. Acutis, M. Bartoli et al., "Origin and fate of nitrates in groundwater from the central Po plain: insights from isotopic investigations," Applied Geochemistry, vol. 34, pp. 164-180, 2013.

[26] M. M. Stoewer, K. Knöller, and C. Stumpp, “Tracing freshwater nitrate sources in pre-alpine groundwater catchments using environmental tracers," Journal of Hydrology, vol. 524, pp. 753-767, 2015.

[27] H. Kim, D. Kaown, B. Mayer, J. Y. Lee, Y. Hyun, and K. K. Lee, "Identifying the sources of nitrate contamination of groundwater in an agricultural area (Haean basin, Korea) using isotope and microbial community analyses," Science of the Total Environment, vol. 533, pp. 566-575, 2015.

[28] D. Widory, E. Petelet-Giraud, P. Négrel, and B. Ladouche, "Tracking the sources of nitrate in groundwater using coupled nitrogen and boron isotopes: a synthesis," Environmental Science \& Technology, vol. 39, no. 2, pp. 539-548, 2005.

[29] K. Tirez, W. Brusten, D. Widory et al., "Boron isotope ratio $\left(\delta^{11} \mathrm{~B}\right)$ measurements in Water Framework Directive monitoring programs: comparison between double focusing sector field ICP and thermal ionization mass spectrometry," Journal of Analytical Atomic Spectrometry, vol. 25, no. 7, pp. 964974, 2010.

[30] R. L. Seiler, "Combined use of ${ }^{15} \mathrm{~N}$ and ${ }^{18} \mathrm{O}$ of nitrate and ${ }^{11} \mathrm{~B}$ to evaluate nitrate contamination in groundwater," Applied Geochemistry, vol. 20, no. 9, pp. 1626-1636, 2005.

[31] C. H. Jeong, "Effect of land use and urbanization on hydrochemistry and contamination of groundwater from Taejon area, Korea," Journal of Hydrology, vol. 253, no. 1-4, pp. 194-210, 2001.

[32] A. Moratalla, J. J. Gómez-Alday, J. de las Heras, D. Sanz, and S. Castaño, "Nitrate in the water-supply wells in the Mancha oriental hydrogeological system (SE Spain)," Water Resources Management, vol. 23, no. 8, pp. 1621-1640, 2009.

[33] M. Vidal, J. Melgar, A. Lopez, and M. C. Santoalla, "Spatial and temporal hydrochemical changes in groundwater under the contaminating effects of fertilizers and wastewater," Journal of Environmental Management, vol. 60, no. 3, pp. 215-225, 2000.

[34] S. J. Rodvang, D. M. Mikalson, and M. C. Ryan, "Changes in ground water quality in an irrigated area of southern Alberta," Journal of Environmental Quality, vol. 33, no. 2, pp. 476-487, 2004.

[35] X. Z. Zeng and J. Sun, "The actuality of organic fertilizer input into arable land and the measure to develop soil fertility in Zunyi prefecture," Cult Plant, vol. 5, pp. 59-60, 1999.

[36] X. H. Chen, "Variations of soil nutrient content and fertilization in Guizhou," Plant Nutrition and Fertilizer Science, vol. 7, no. 2, pp. 121-128, 2001.

[37] K.-H. Kim, S.-T. Yun, B. Mayer, J. H. Lee, T. S. Kim, and H. K. Kim, "Quantification of nitrate sources in groundwater using hydrochemical and dual isotopic data combined with a Bayesian mixing model," Agriculture, Ecosystems and Environment, vol. 199, pp. 369-381, 2015.

[38] E. Pastén-Zapata, R. Ledesma-Ruiz, T. Harter, A. I. Ramírez, and J. Mahlknecht, "Assessment of sources and fate of nitrate in shallow groundwater of an agricultural area by using a multi-tracer approach," Science of the Total Environment, vol. 470-471, pp. 855-864, 2014.

[39] K. Nakagawa, H. Amano, H. Asakura, and R. Berndtsson, "Spatial trends of nitrate pollution and groundwater chemistry 
in Shimabara, Nagasaki, Japan," Environmental Earth Sciences, vol. 75, no. 3, 2016.

[40] J. Velić and G. Durn, “Alternating lacustrine-marsh sedimentation and subaerial exposure phases during Quaternary: Prečko, Zagreb, Croatia," Geologia Croatica, vol. 46, no. 1, pp. 7190, 1993.

[41] J. Velić, B. Saftić, and T. Malvić, "Lithologic composition and stratigraphy of Quaternary sediments in the area of the "Jakuševec" Waste Depository (Zagreb, Northern Croatia)," Geologia Croatica, vol. 52, no. 2, pp. 119-130, 1999.

[42] J. Velić and B. Saftić, "Subsurface spreading and facies characteristics of Middle Pleistocene deposits between Zaprešić and Samobor," Geološki vjesnik, vol. 44, pp. 69-82, 1991.

[43] S. Ružičić, M. Mileusnić, and K. Posavec, "Building conceptual and mathematical model for water flow and solute transport in the unsaturated zone at Kosnica site," The Mining-GeologyPetroleum Engineering Bulletin, vol. 25, pp. 21-31, 2012.

[44] S. Ružičić, Z. Kovač, Z. Nakić, and D. Kireta, "Fluvisol permeability estimation using soil water content variability," Geofi$z i k a$, vol. 34, no. 1, pp. 141-155, 2017.

[45] Z. Nakić, K. Posavec, J. Parlov, and A. Bačani, "Development of the conceptual model of the Zagreb aquifer system," in The Geology in Digital Age: Proceedings of the 17th Meeting of the Association of European Geological Societies, MAEGS 17, Belgrade, Serbia, 2011.

[46] K. Posavec, P. Vukojević, M. Ratkaj, and T. Bedeniković, "Cross-correlation modelling of surface water-groundwater interaction using the Excel spreadsheet application," The Mining-Geology-Petroleum Engineering Bulletin, vol. 32, no. 1, pp. 25-32, 2017.

[47] T. Marković, Ž. Brkić, and O. Larva, "Using hydrochemical data and modelling to enhance the knowledge of groundwater flow and quality in an alluvial aquifer of Zagreb, Croatia," Science of the Total Environment, vol. 458-460, pp. 508-516, 2013.

[48] "CORINE Land Cover Croatia for year 2012," Croatian Agency for Environment and Nature, 2013, http://corine.azo.hr/corine/hr\#sthash.zEkKyX4D.dpbs.

[49] T. C. Hollocher, "Source of the oxygen atoms of nitrate in the oxidation of nitrite by Nitrobacter agilis and evidence against a $\mathrm{P}-\mathrm{O}-\mathrm{N}$ anhydride mechanism in oxidative phosphorylation," Archives of Biochemistry and Biophysics, vol. 233, no. 2, pp. 721-727, 1984.

[50] IAEA (International Atomic Energy Agency)/WMO (World Meteorological Organization), WISER Database, 2017, https://nucleus.iaea.org/wiser/gnip.php?ll_latlon=\&ur_latlon= $\&$ country=Croatia\&wmo_region $=\&$ date_start $=1953 \&$ date end=2016\&iso_o18=on\&iso_h2=on\&action $=$ Search.

[51] T. B. Coplen and L. I. Wassenaar, "LIMS for lasers 2015 for achieving long-term accuracy and precision of $\delta^{2} \mathrm{H}, \delta^{17} \mathrm{O}$, and $\delta^{18} \mathrm{O}$ of waters using laser absorption spectrometry," Rapid Communications in Mass Spectrometry, vol. 29, no. 22, pp. 2122-2130, 2015.

[52] Dell Inc., Dell Statistica (Data Analysis Software System), Version 13, 2016, http://software.dell.com.

[53] J. F. J. Hair, W. C. Black, J. B. Barry, and R. E. Anderson, Multivariate Data Analysis, Seventh edition, Prentice Hall, Upper Saddle River, NJ, USA, 2010.

[54] R. C. MacCallum, K. F. Widaman, S. Zhang, and S. Hong, "Sample size in factor analysis," Psychological Methods, vol. 4, no. 1, pp. 84-99, 1999.
[55] J. Parlov, Z. Nakić, K. Posavec, and A. Bačani, "Origin and dynamics of aquifer recharge in Zagreb area," in The Fifth International Scientific Conference on Water, Climate and Environment, Balwois, Ohrid, Macedonia, May-June 2012.

[56] T. B. Spruill, W. J. Showers, and S. S. Howe, "Application of classification-tree methods to identify nitrate sources in ground water," Journal of Environmental Quality, vol. 31, no. 5, pp. 1538-1549, 2002.

[57] A. Menció, J. Mas-Pla, N. Otero et al., "Nitrate pollution of groundwater; all right..., but nothing else?," Science of the Total Environment, vol. 539, pp. 241-251, 2016.

[58] G. Martinelli, A. Dadomo, D. A. de Luca et al., "Nitrate sources, accumulation and reduction in groundwater from Northern Italy: insights provided by a nitrate and boron isotopic database," Applied Geochemistry, vol. 91, pp. 23-35, 2018.

[59] Croatian Waters, Draft Version of Croatian River Basin Management Plan for 2016-2021 Period, 2015, http://www. voda.hr/sites/default/files/dokumenti/nacrt_plana_upravljanja_ vodnim_podrucjima.pdf. 

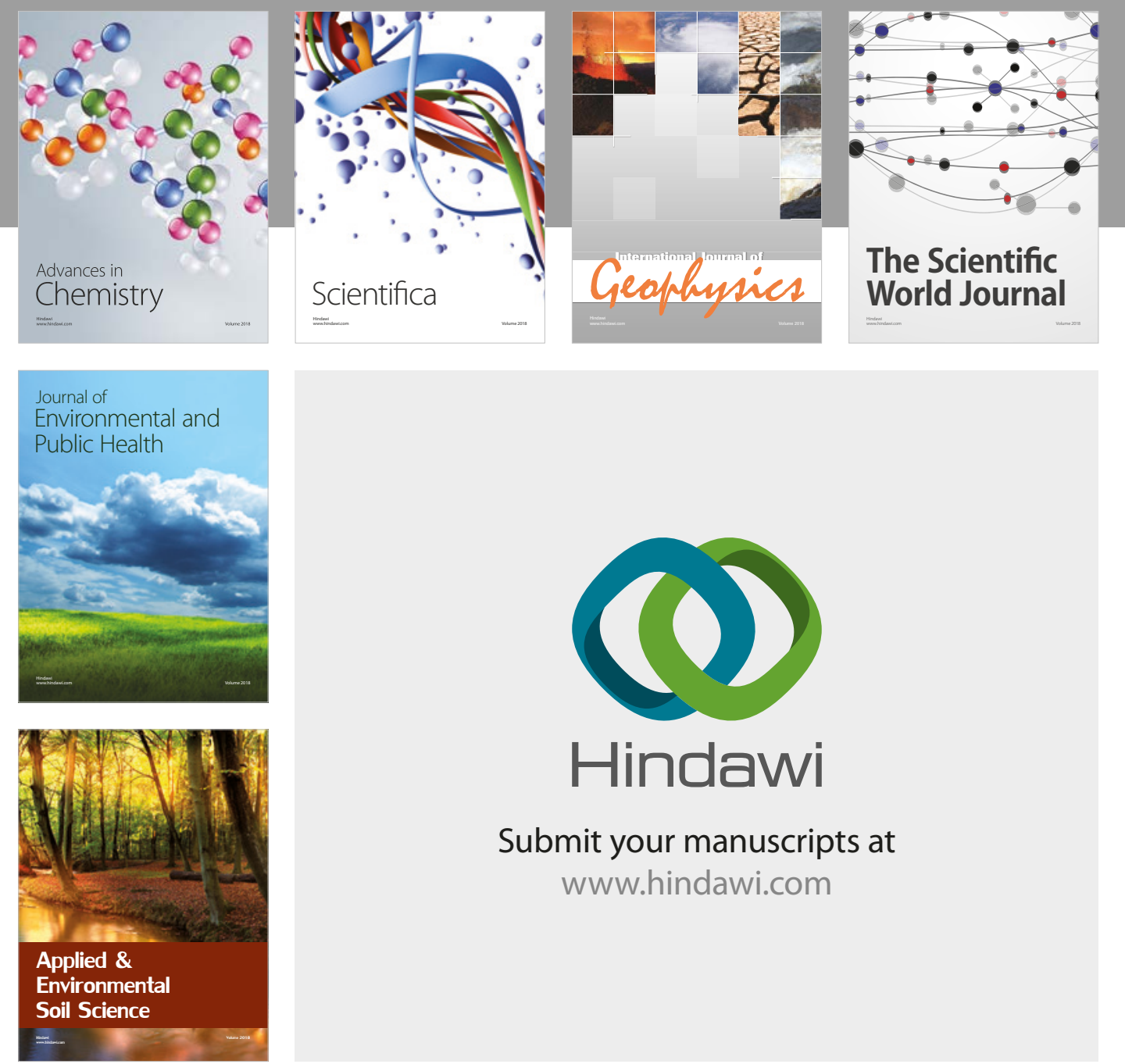

The Scientific

\section{World Journal}
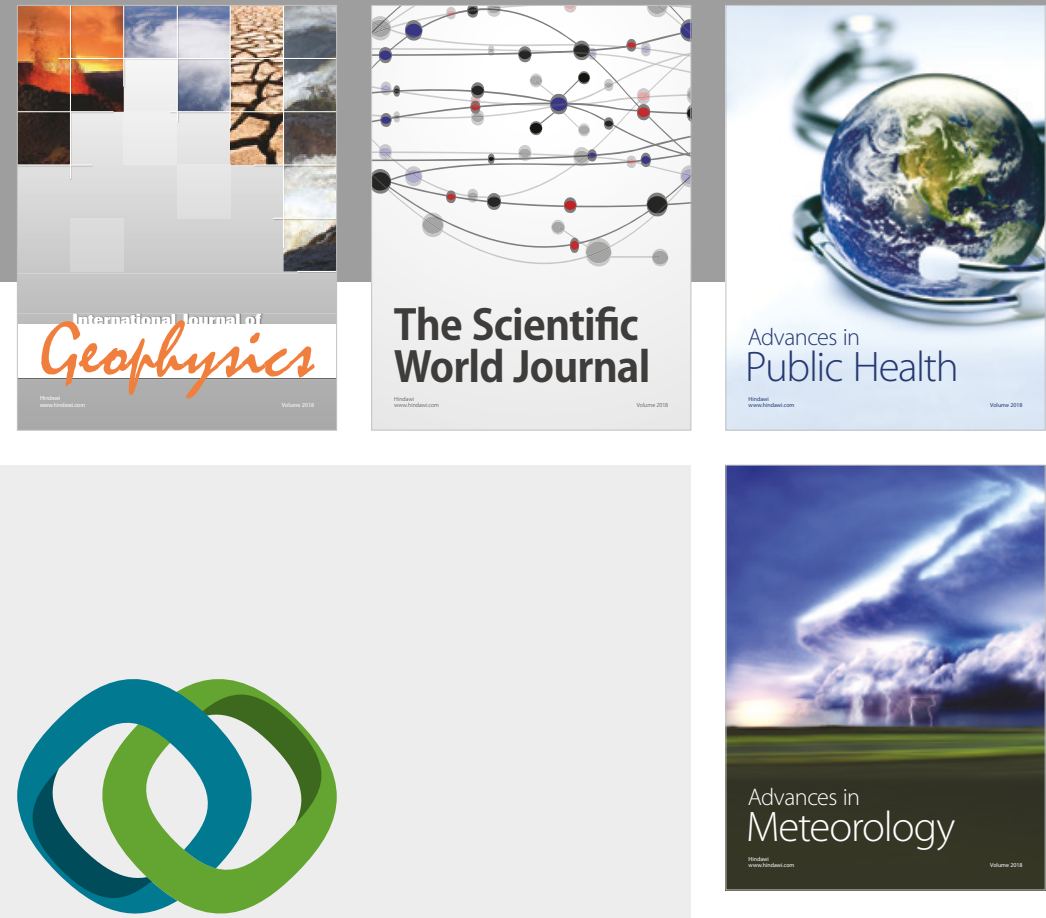

Advan

Public Health

\section{Hindawi}

Submit your manuscripts at

www.hindawi.com
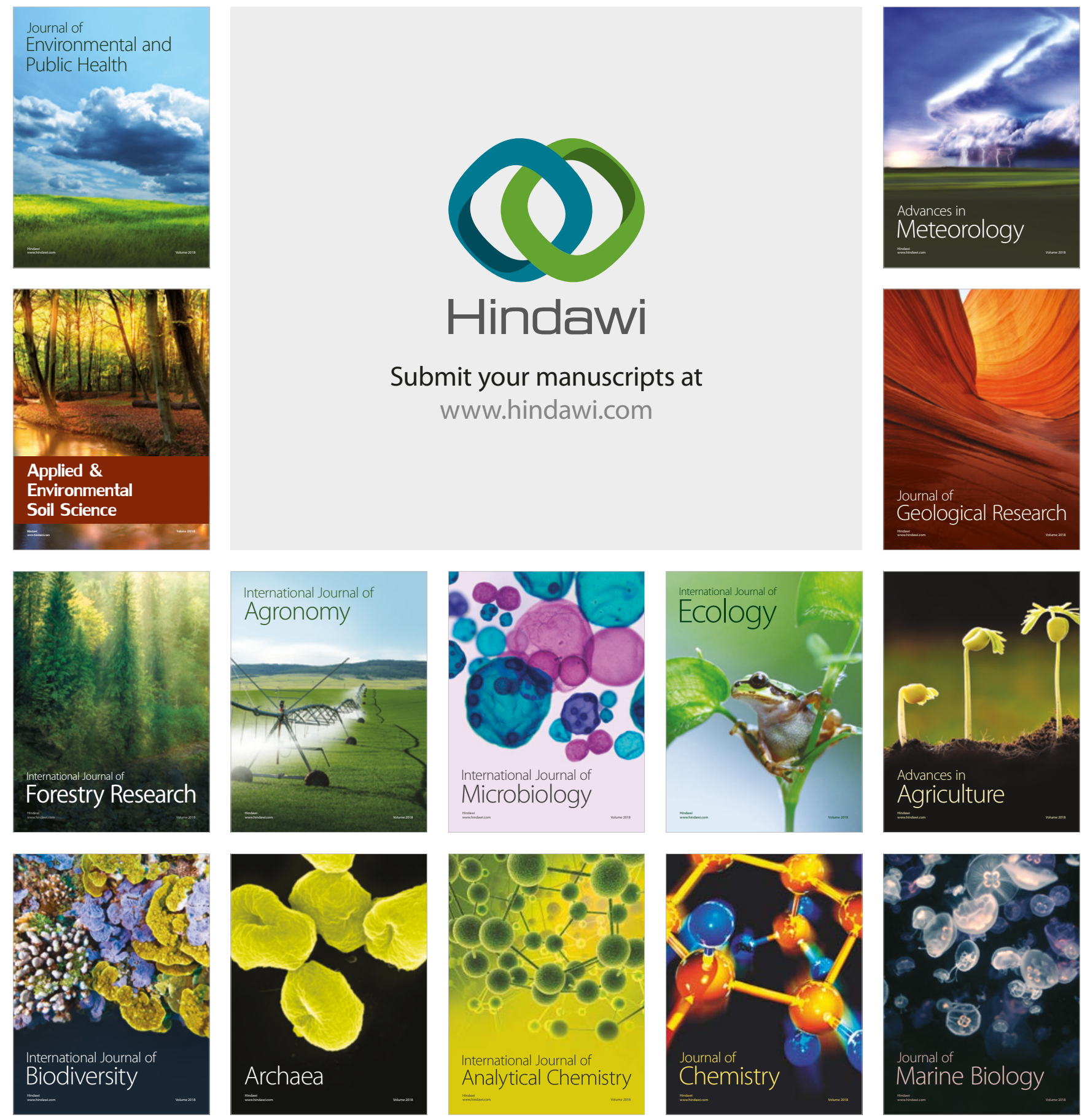